OPEN ACCESS

Edited by:

Fabian Cieplik,

University Medical Center

Regensburg, Germany

Reviewed by:

Teruaki Nakatsuji.

University of California, San Diego,

United States

Michael Otto,

National Institutes of Health $(\mathrm{NIH})$,

United States

*Correspondence:

Joanna Nakonieczna

joanna.nakonieczna

@biotech.ug.edu.pl

orcid.org/0000-0002-2420-664X

Specialty section:

This article was submitted to Antimicrobials, Resistance

and Chemotherapy,

a section of the journal

Frontiers in Microbiology

Received: 29 May 2020 Accepted: 14 December 2020

Published: 11 January 2021

Citation:

Ogonowska P, Gilaberte Y,

Barańska-Rybak $W$ and

Nakonieczna J (2021) Colonization

With Staphylococcus aureus in Atopic

Dermatitis Patients: Attempts

to Reveal the Unknown.

Front. Microbiol. 11:567090.

doi: 10.3389/fmicb.2020.567090

\section{Colonization With Staphylococcus aureus in Atopic Dermatitis Patients: Attempts to Reveal the Unknown}

\author{
Patrycja Ogonowska ${ }^{1}$, Yolanda Gilaberte ${ }^{2}$, Wioletta Barańska-Rybak ${ }^{3}$ and \\ Joanna Nakonieczna ${ }^{1 *}$
}

'Laboratory of Molecular Diagnostics, Intercollegiate Faculty of Biotechnology University of Gdańsk and Medical University of Gdańsk, Gdańsk, Poland, ${ }^{2}$ Department of Dermatology, University Hospital Miguel Servet, Zaragoza, Spain, ${ }^{3}$ Department of Dermatology, Venereology and Allergology, Medical University of Gdańsk, Gdańsk, Poland

Atopic dermatitis (AD) patients are massively colonized with Staphylococcus aureus (S. aureus) in lesional and non-lesional skin. A skin infection may become systemic if left untreated. Of interest, the incidence of multi-drug resistant $S$. aureus (MRSA) in $A D$ patients is higher as compared to a healthy population, which makes treatment even more challenging. Information on the specific genetic background of $S$. aureus accompanying and/or causing $A D$ flares would be of great importance in terms of possible treatment option development. In this review, we summarized the data on the prevalence of $S$. aureus in general in AD skin, and the prevalence of specific clones that might be associated with flares of eczema. We put our special interest in the presence and role of staphylococcal enterotoxins as important virulence factors in the epidemiology of AD-derived S. aureus. Also, we summarize the present and potentially useful future anti-staphylococcal treatment.

Keywords: epidemiology of S. aureus, MRSA, staphylococcal enterotoxins, antistaphylococcal photodynamic treatment, virulence factor

\section{INTRODUCTION}

Atopic dermatitis (AD), also known as atopic eczema, is a chronic and relapsing inflammatory skin disorder. It may coexist with other atopic conditions: allergic rhinitis (hay fever), bronchial asthma and food allergy. AD mainly affects infants and young children. Nevertheless, it can persist or appear during puberty and adulthood. AD occurs commonly in $15-30 \%$ of children and $2-10 \%$ of adults worldwide (Silverberg, 2017).

In 1980, Hanifin and Rajka proposed criteria for diagnosing AD. According to the published guidelines, patients diagnosed with AD should present three or more basic features (e.g., pruritus, lichenification, atopic history) and three or more minor features (e.g., xerosis, early age of onset, food intolerance) (Hanifin and Rajka, 1980). Furthermore, various scoring systems have been established to measure disease severity. SCORAD (Severity Scoring Index of Atopic Dermatitis) evaluates the intensity of atopic signs in general in addition to the symptoms (pruritus and sleep) (Kunz et al., 1997), whereas EASI (Eczema Area and Severity Index) evaluates the severity of AD in four different parts of the body (head and neck, upper limbs, trunk and lower limbs) (Hanifin et al., 2001; Housman et al., 2002). SASSAD (Six Area Six Sign Atopic Dermatitis Atopic Score) less used includes six signs of $\mathrm{AD}$ (cracking, dryness, erythema, excoriation, exudation, and lichenification), their severity in a four-point scale (0-absent, 1 -mild, 2-moderate and 3-severe) on the most 


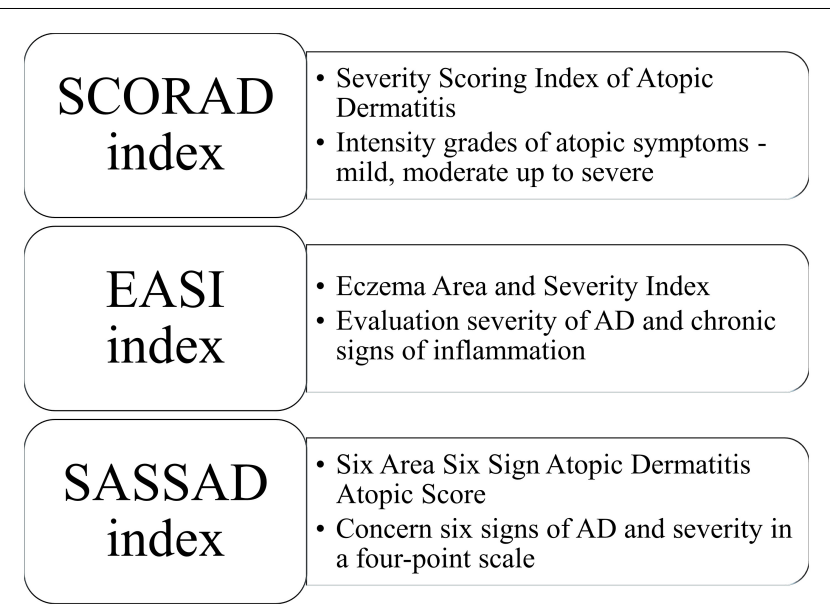

FIGURE 1 | Various scoring systems for diagnosing atopic dermatitis.

following sites of different parts of the body (head and neck, arms, hands, trunk, legs, and feet) (Figure 1; Berth-Jones and BerthJones, 1996).

Currently, $\mathrm{AD}$ is considered a multifactorial skin disorder, with still not fully understood pathogenesis. The development of $\mathrm{AD}$ is a result of interactions between skin barrier defects and genetic, immunological and environmental factors (e.g., dust mite, tobacco smoke, soap, diet, air pollution, hygiene, stress) (Ring et al., 1992; Bonamonte et al., 2019). Patients suffering from atopic eczema revealed significantly reduced quality of life due to itching, which leads to sleep disturbances (Blome et al., 2016). The severe form of AD had a significant impact on the quality of life in adult patients compared to the mild and moderate types of AD (Chiesa Fuxench et al., 2019). Moreover, AD is a serious socio-economic problem in health care units because of the long treatment duration and financial costs (Carroll et al., 2005).

In addition to the long-term and burdensome treatment of $\mathrm{AD}$ patients, colonization by Staphylococcus aureus is another serious problem. Staphylococcus aureus is associated with the severity, pathogenesis and exacerbation of $\mathrm{AD}$.

\section{INCREASED STAPHYLOCOCCUS AUREUS COLONIZATION RATE FOR AD PATIENTS}

The phenomenon of $S$. aureus colonization in $\mathrm{AD}$ patients has been known for a long time (Leyden and Marples, 1973; Hauser et al., 1985). Hauser et al. demonstrated higher S. aureus density, S. aureus fraction (SAF index) and total CFU $/ \mathrm{cm}^{2}$ (CFU-colony forming units) in the lesional skin in $\mathrm{AD}$ patients than in the healthy control group (Hauser et al., 1985). In children suffering from $\mathrm{AD}, S$. aureus colonization rate is higher than in the healthy group and affects $57-100 \%$ of children (Bunikowski et al., 2000; Arkwright et al., 2001; Lo et al., 2010; Pascolini et al., 2011). More than $40 \%$ of $\mathrm{AD}$ children are colonized both on the lesional skin and in the anterior nares (Pascolini et al., 2011). In children with
$\mathrm{AD}$, the carriage of the $S$. aureus strains in the anterior nares could be a potential source of recolonization (Patel et al., 2001). Results concerning $S$. aureus presence from AD children are summarized in Table 1.

Regarding S. aureus colonization in adult patients, 54-100\% (Breuer et al., 2002; Tomi et al., 2005; Gong et al., 2006; Kim et al., 2009; Na et al., 2012; Rojo et al., 2014; Clausen et al., 2017, 2019) suffering from AD were colonized by this species. S. aureus isolates formed a reservoir in the nose in AD patients. It can be diffused by autotransmission on the skin area (Breuer et al., 2002). The most colonized site is lesional skin (56-96.2\%) (Matsui et al., 2000; Park et al., 2016; Totté et al., 2016; Alsterholm et al., 2017), nose (46.1-64.1\%) (Na et al., 2012; Park et al., 2016; Totté et al., 2016; Clausen et al., 2017), and non-lesional skin (28-39\%) (Matsui et al., 2000; Totté et al., 2016; Clausen et al., 2017). Several studies demonstrated that 65-77.3\% (Breuer et al., 2002; Tomi et al., 2005; Na et al., 2012) of AD patients were colonized both in the anterior nares and on the skin, whereas only $10.2 \%$ of healthy control subjects were colonized on the skin (Matsui et al., 2000). Alsterholm et al. (2017) found that $55 \%$ of the AD patients were persistent carriers of $S$. aureus. Moreover, persistent $S$. aureus carriers had a higher SCORAD than intermittent carriers or noncarriers. It turns out that not only the nose but also the skin could be an important reservoir of $S$. aureus in AD patients (Alsterholm et al., 2017). Frequent recolonization by $S$. aureus between nose and skin was observed, which can contribute to the severity of AD (Chiu et al., 2009). Results concerning the distribution of S. aureus in adults are summarized in Table 2 .

High S. aureus colonization rate is observed in both groups, children and adults. Colonization rate increases with the severity of the $\mathrm{AD}$, and it acts as an aggravating factor exacerbating inflammation (Breuer et al., 2002). Also, colonization with $S$. aureus in $\mathrm{AD}$ patients could be a potent risk of various invasive infections, e.g., bacteremia, septic shock, osteomyelitis, necrotizing pneumonia, or septic arthritis (Patel and Jahnke, 2015).

\section{MRSA VS. MSSA DISTRIBUTION IN ATOPIC DERMATITIS}

Among S. aureus isolates, methicillin-resistant S. aureus (MRSA) constitutes an important and significant group that requires particular concern. MRSA is a group of strains that are resistant to multiple $\beta$-lactam antibiotics (cephalosporins, carbapenems, monobactams, and penicillins). This phenotype results in limited treatment options, including for skin infections (Rangel and Paller, 2018). It has been demonstrated that among S. aureus strains colonizing AD patients, the percentage of MRSA is 4-13 times higher than in a healthy population (Suh et al., 2008; Lo et al., 2010).

Currently, three profiles of MRSA are distinguished: hospital-associated (HA-MRSA), community-associated (CAMRSA), and livestock-associated MRSA (LA-MRSA). Initially, epidemiological investigations indicated that MRSA infections related only to hospitalized patients (HA-MRSA). However, later it turned out that MRSA can also be isolated from infected 
TABLE 1 | The distribution of $S$. aureus colonization and toxins production in children with atopic dermatitis.

\begin{tabular}{|c|c|c|c|c|}
\hline References & Examined groups & Sites of isolation & $\begin{array}{l}\text { Colonization staphylococcus } \\
\text { aureus }\end{array}$ & Toxins production \\
\hline $\begin{array}{l}\text { Bunikowski et al. (2000) } \\
\text { Germany }\end{array}$ & $\begin{array}{l}\text { Children with AD } \\
(n=74) \\
\text { Healthy control patients } \\
(n=25)\end{array}$ & $\begin{array}{l}\text { Unaffected and } \\
\text { eczematous skin } \\
\text { lesions } \\
\text { Neck } \\
\text { Wrist } \\
\text { Elbow } \\
\text { Erosive eczematous } \\
\text { lesions }\end{array}$ & $\begin{array}{l}\text { AD patients } 60(81 \%) \text { were S. aureus } \\
\text { positive [including } 40(53 \%) \text { toxigenic } \\
\text { S. aureus strains] } \\
\text { Healthy controls } 5(20 \%) \text { were } \\
\text { S. aureus positive [including } 1 \text { toxigenic } \\
\text { S. aureus strain] }\end{array}$ & $\begin{array}{l}\text { AD patients sea: } 12, \text { seb: } 9, \\
\text { sec: } 12, \text { sed: } 3, \text { tsst- } 1: 9 \\
\underline{\text { Healthy controls sea: } 1}\end{array}$ \\
\hline $\begin{array}{l}\text { Arkwright et al. (2001) } \\
\text { United Kingdom }\end{array}$ & $\begin{array}{l}\text { Children with AD } \\
(n=28)\end{array}$ & $\begin{array}{l}\text { Eczematous lesions } \\
\text { Nares }\end{array}$ & $\begin{array}{l}\text { Each of the examined patients was } \\
\text { colonized }\end{array}$ & 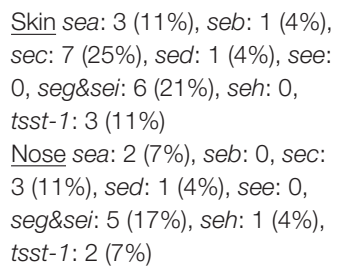 \\
\hline $\begin{array}{l}\text { Lomholt et al. (2005) } \\
\text { Denmark }\end{array}$ & $\begin{array}{l}\text { Children with } A D \\
(n=11)\end{array}$ & $\begin{array}{l}\text { Anterior nares } \\
\text { Axillae } \\
\text { Area of active eczema } \\
\text { Perineum }\end{array}$ & No data & $\begin{array}{l}\text { sea: } 8(29 \%), \text { seb: } 1(4 \%), \text { sec: } \\
1(4 \%), \text { sed: } 0(0 \%), \text { tsst-1: } 0 \\
(0 \%)\end{array}$ \\
\hline $\begin{array}{l}\text { Lo et al. (2010) } \\
\text { Taiwan }\end{array}$ & $\begin{array}{l}\text { Children with AD } \\
(n=133) \\
\text { Children with AD and } \\
\text { SSTI }(n=20) \\
\text { Healthy controls } \\
(n=490)\end{array}$ & The anterior nares & $\begin{array}{l}\text { Children with AD } 67 \text { isolates were } \\
\text { positive for S. aureus } \\
\text { ( } 23 \text { MRSA and } 44 \text { MSSA) } \\
\text { Children with AD and SSTI } 20 \text { isolates } \\
\text { were positive for S. aureus } \\
\text { (12 MRSA and } 8 \text { MSSA) } \\
\text { Healthy controls } 170 \text { isolates were } \\
\text { positive for S. aureus } \\
\text { (44 MRSA and } 126 \text { MSSA) }\end{array}$ & $\begin{array}{l}\text { Results from molecular } \\
\text { characteristics of } 79 \text { MRSA } \\
\text { isolates from } 643 \text { children } \\
\text { Children with AD sea: } 1 \text { (4\%), } \\
\text { seb: } 20 \text { ( } 87 \%) \text {, sec: } 2 \text { ( } 9 \%), \\
\text { sed: 0, seg/sei: } 1 \text { (4\%), seh: } 1 \\
\text { (4\%), tsst-1: } 2 \text { (9\%), } \\
\text { Children with AD and SSTI sea: } \\
\text { 0, seb: } 12 \text { (100\%), sec: 0, sed: } \\
\text { 0, seg/sei: 0, seh: } 1 \text { (8\%), } \\
\text { tsst-1: 0, } \\
\text { Healthy controls sea: } 3(7 \%), \\
\text { seb: } 28 \text { (64\%), sec: } 11(25 \%), \\
\text { sed: } 1 \text { (2\%), seg/sei: } 11(25 \%), \\
\text { seh: 0, tsst-1: } 7 \text { (16\%) }\end{array}$ \\
\hline $\begin{array}{l}\text { Pascolini et al. (2011) } \\
\text { Italy }\end{array}$ & $\begin{array}{l}\text { Children with AD } \\
(n=117) \\
\text { Healthy controls } \\
(n=90)\end{array}$ & $\begin{array}{l}\text { Skin lesions } \\
\text { Normal skin areas } \\
\text { Nares }\end{array}$ & $\begin{array}{l}\text { Children with AD } 66 \text { patients (57\%) } \\
\text { - lesional skin and nares: } 47 \text { (40.2\%) } \\
\text { - nares: } 19 \text { (16.2\%) } \\
\text { - uninvolved skin: } 4(3.4 \%) \\
\text { Healthy children } 18 \text { patients (20\%) } \\
\text { - nares: } 18 \\
\text { - uninvolved skin: } 0\end{array}$ & 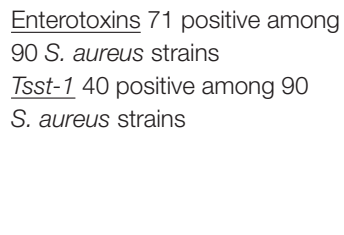 \\
\hline $\begin{array}{l}\text { Park et al. (2013) } \\
\text { Korea }\end{array}$ & $\begin{array}{l}\text { Infants with AD } \\
(\mathrm{n}=188) \\
\text { Children with } \mathrm{AD} \\
(n=267) \\
\text { Control group- } \\
\text { patients with urticaria } \\
(n=247)\end{array}$ & $\begin{array}{l}\text { Skin lesions } \\
\text { (acute and chronic) }\end{array}$ & $\begin{array}{l}\text { Infantsacute lesion: 50\% (18/36) } \\
\text { - chronic lesion: } 18.5 \%(28 / 151) \\
\text { Childrenacute lesion: 80\% (44/55) } \\
\text { - chronic lesion: } 41.8 \%(90 / 215)\end{array}$ & No data \\
\hline $\begin{array}{l}\text { Gilaberte et al. (2015) } \\
\text { Spain }\end{array}$ & $\begin{array}{l}\text { Children with AD } \\
(n=114)\end{array}$ & $\begin{array}{l}\text { Clinically uninfected } \\
\text { lesional skin } \\
\text { (antecubital or popliteal } \\
\text { areas) } \\
\text { Nares }\end{array}$ & $\begin{array}{l}\text { Skin: } 32 / 113(28.3 \%) \\
\text { Nares: } 20 / 85(23.5 \%) \\
\text { All S. aureus strains were MSSA except } \\
\text { one MRSA isolated from the skin }\end{array}$ & $\begin{array}{l}\text { Skin and nasal isolates seb: } 1 \\
(2.5 \%), \text { sec: } 2(5 \%), \text { tsst- } 1: 22 \\
(55 \%) \\
\text { Skin isolates seb: } 0, \text { sec: } 2 \\
(7.7 \%), \text { tsst- } 1: 13(50 \%)\end{array}$ \\
\hline $\begin{array}{l}\text { Abad et al. (2019) } \\
\text { Brazil }\end{array}$ & $\begin{array}{l}\text { Children with } A D \\
(n=117)-2 \\
\text { months }-14 \text { years old }\end{array}$ & Nasal swabs & $\begin{array}{l}\text { 97/117 of patients (82.90\%) were } \\
\text { colonized with S. aureus } \\
\text { - 26/97 (22.22\%) MRSA } \\
\text { - } 71 / 97(60.68 \%) \text { MSSA }\end{array}$ & No data \\
\hline
\end{tabular}


TABLE 2 | The distribution of $S$. aureus colonization and toxins production in adults with atopic dermatitis.

\begin{tabular}{|c|c|c|c|c|}
\hline References & Examined groups & Sites of isolation & $\begin{array}{l}\text { Colonization of staphylococcus } \\
\text { aureus }\end{array}$ & Toxins production \\
\hline $\begin{array}{l}\text { Zollner et al. (2000) } \\
\text { Germany }\end{array}$ & $\begin{array}{l}\text { AD patients }(n=33) \\
\text { Atopic controls }(n=21) \\
\text { Healthy controls } \\
(n=50)\end{array}$ & $\begin{array}{l}\text { AD patients: mucous } \\
\text { membranes (nose and } \\
\text { throat), involved skin } \\
\text { Healthy controls: } \\
\text { healthy skin of the } \\
\text { elbows }\end{array}$ & $\begin{array}{l}\text { AD patients: } 23 / 33(69.70 \%) \\
\text { Atopic controls: } 9 / 21(42.86 \%) \\
\text { Healthy controls: } 15 / 50(30 \%)\end{array}$ & $\begin{array}{l}\text { AD patients } 13 / 23(57 \%) \\
\text { isolates produced SEs } \\
\text { seb }(5 / 13,38 \%), \text { sec }(1 / 13, \\
8 \%), \text { sed }(1 / 13,8 \%), \text { tsst-1 } \\
(3 / 13,23 \%) \\
\text { Atopic controls } 3 / 9(33 \%) \\
\text { isolates produced SEs } \\
\text { sea }(2 / 3,66 \%), \text { seb }(1 / 3,33 \%) \text {, } \\
\text { tsst- } 1(1 / 3,33 \%) \\
\text { Healthy controls } 5 / 15(33 \%) \\
\text { isolates produced SEs } \\
\text { sea }(1 / 5,20 \%), \text { seb }(1 / 5,20 \%) \text {, } \\
\text { tsst- } 1(3 / 5,60 \%)\end{array}$ \\
\hline $\begin{array}{l}\text { Breuer et al. (2002) } \\
\text { Germany }\end{array}$ & $\begin{array}{l}\text { Patients with AD-adults } \\
(n=66)\end{array}$ & $\begin{array}{l}\text { Skin } \\
\text { Anterior nares }\end{array}$ & $\begin{array}{l}62 \text { of the } 66 \text { patients (94\%) } \\
\text { - skin(+), nose(+): } \\
51(77.3 \%) \\
\text { - skin(+), nose(-): } \\
7(10.6 \%) \\
\text { - skin(-). nose }(+) \text { : } \\
\quad 4(6.1 \%) \\
\text { - skin }(-), \text { nose }(-) \text { : } \\
\quad 4(6.1 \%)\end{array}$ & $\begin{array}{l}\text { Cutaneous and nasal isolates } \\
\text { from } 32 \text { patients were included } \\
\text { in the study. } \\
10(31 \%) \text { of the patients were } \\
\text { colonized with toxigenic } \\
\text { S. aureus } \\
\underline{\text { Skin }} \\
\text { sea }=\text { sed }>\text { seb }>\text { sec }=\text { tsst- } 1 \\
\underline{\text { Nose sed }>\text { seb }>\text { sea }=\text { sec }} \\
\text { tsst- } 1 \text { was not detected }\end{array}$ \\
\hline $\begin{array}{l}\text { Schlievert et al. (2008) } \\
\text { United States }\end{array}$ & $\begin{array}{l}\text { Group } 1 \text { isolates } \\
\text { Patients with } \\
\text { steroid-resistant atopic } \\
\text { dermatitis }(n=78) \\
\text { Group } 2 \text { isolates } \\
\text { Healthy women vaginas } \\
(n=30) \\
\text { Group } 3 \text { isolates } \\
\text { Patients with atopic } \\
\text { dermatitis }(n=22)\end{array}$ & $\begin{array}{l}\text { Group } 1 \text { isolates: } 4 \text { the } \\
\text { most affected } \\
\text { eczematous lesions }\end{array}$ & No data & 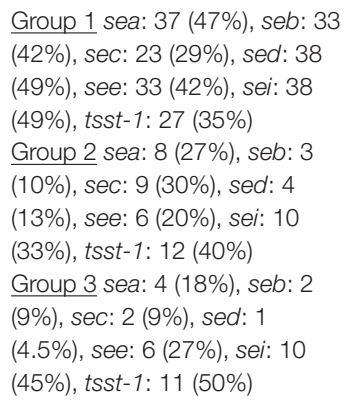 \\
\hline $\begin{array}{l}\text { Kim et al. (2009) } \\
\text { Korea }\end{array}$ & $\begin{array}{l}\text { Adolescent or adult } \\
\text { patients with AD } \\
(n=42)\end{array}$ & $\begin{array}{l}\text { The eczematous } \\
\text { lesions: } \\
\text { Lateral neck } \\
\text { Forearm } \\
\text { Abdomen } \\
\text { Popliteal area }\end{array}$ & 35 of the 42 patients (83.3\%) & $\begin{array}{l}\text { sea: } 35 \text { (97.2\%), seb: } 1 \text { (2.8\%), } \\
\text { sec: 0, sed: } 5 \text { (13.9\%), see: 0, } \\
\text { tsst-1: } 35(97.2 \%)\end{array}$ \\
\hline $\begin{array}{l}\text { Park et al. (2013) } \\
\text { Korea }\end{array}$ & $\begin{array}{l}\text { Adults with AD } \\
(n=232) \\
\text { Control } \\
\text { group-patients with } \\
\text { urticaria }(n=247)\end{array}$ & $\begin{array}{l}\text { Skin lesions } \\
\text { (acute and chronic) }\end{array}$ & $\begin{array}{l}\text { Adults } \\
\text { - acute lesions: } 87.5 \%(35 / 40) \\
\text { - chronic lesions: 48.9\% (93/190) }\end{array}$ & No data \\
\hline $\begin{array}{l}\text { Alsterholm et al. (2017) } \\
\text { Sweden }\end{array}$ & $\begin{array}{l}\text { Patients with } A D \\
(n=21)\end{array}$ & $\begin{array}{l}\text { Lesional skin } \\
\text { Anterior nares } \\
\text { Perineum } \\
\text { Tonsils } \\
\text { Non-lesional skin }\end{array}$ & $\begin{array}{l}\text { Lesional skin: } 57-65 \% \\
\text { Non-lesional skin: } \\
53-71 \% \\
\text { Anterior nares: 53-67\% } \\
\text { Tonsils: } 24-30 \% \\
\text { Perineum: } 32-55 \%\end{array}$ & No data \\
\hline $\begin{array}{l}\text { Clausen et al. (2019) } \\
\text { Denmark }\end{array}$ & AD patients $(n=63)$ & $\begin{array}{l}\text { Lesional skin } \\
\text { Non-lesional skin } \\
\text { Nose }\end{array}$ & $\begin{array}{l}34 \text { of patients (54\%): } \\
\text { - lesional skin: } 33 \% \\
\text { - non-lesional skin: } 10 \% \\
\text { - nose: } 41 \%\end{array}$ & No data \\
\hline
\end{tabular}


people that have not been exposed to healthcare-related risks (CA-MRSA). The first outbreak of CA-MRSA was described in 1981 in the United States (Saravolatz et al., 1982) and nowadays is associated with skin and soft tissue infections (King et al., 2006; Chung et al., 2008). The skin of patients with $\mathrm{AD}$ could be a favorable reservoir for CA-MRSA. In the United States, $18.3 \%$ of AD patients are colonized with CA-MRSA (Chung et al., 2008). Colonization with MRSA constitutes the best-known risk factor for developing infection and MRSA can be easily transferred via direct skin-to-skin contact in the public settings, e.g., gyms, thus spreading the bacteria further. Reported in recent years, LA-MRSA is of animal origin, but it has also been detected in humans (van Cleef et al., 2011). It typically causes skin and soft tissue infections (SSTI) as well as more severe infections, similar to HA- and CA-MRSA. Some epidemiological data on the prevalence of LA-MRSA skin and soft tissue infections account for $15 \%$ of all MRSA SSTI infections in the community (Butaye et al., 2016). However, similar data in the AD population are not currently available.

Nasal carriage of $S$. aureus plays a vital role in the epidemiology and pathogenesis of AD disease. Nevertheless, the distribution of MRSA strains among AD patients is still divergent in the worldwide population. Among $S$. aureus-positive swabs from the anterior nares of $\mathrm{AD}$ patients, 34\% were MRSA, in contrast to $26 \%$ from healthy children (Lo et al., 2010). In another study carried out in Brazilian AD children, $22.22 \%$ of $S$. aureus isolated strains were MRSA. On the other hand, when Korean AD children skin lesions were screened, $18.4 \%$ S. aureus strains were MRSA. Finally, among the isolates from AD children from Italy, only $7.9 \%$ were MRSA $(12.8 \%$ from the skin lesion and $4.5 \%$ from the nose) (Chung et al., 2008; Pascolini et al., 2011). Moreover, they indicated that children with $\mathrm{AD}$ who had contact with wounds and pus at home or with persons colonized by MRSA had an increased risk of acquisition MRSA. In the case of adults with $\mathrm{AD}$, the overall distribution of MRSA isolates seems to be much lower (Kim et al., 2009) or even absent (Rojo et al., 2014), as compared to the children in $\mathrm{AD}$ population.

Studies mentioned above indicate that the distribution of MRSA isolates among $\mathrm{AD}$ patients reflects an increased prevalence of MRSA in the AD population as compared to healthy ones, in particular in children. Notably, among patients expressing a severe type of $\mathrm{AD}$, a higher risk of MRSA acquisition with time was reported in comparison to patients with a mild or moderate AD type (Abad et al., 2019).

\section{FACTORS PREDISPOSING TO THE S. AUREUS COLONIZATION}

One of the main factors predisposing to the $S$. aureus colonization are changes in the composition of lipids and fatty acids in the skin. In the epidermis (especially in the stratum corneum) significantly lower level of ceramides and higher amount of cholesterol was observed (Figure 2; Murata et al., 1996; Di Nardo et al., 1998). The reduction of skin lipids level could explain the role of these components in maintaining the hydration of the skin (Coderch et al., 2003). Similarly, ceramides and sphingosine levels are reduced in the stratum corneum of AD patients, which may favor $S$. aureus colonization. It was shown that sphingosine reveals the antimicrobial effect against $S$. aureus (Arikawa et al., 2002). Furthermore, S. aureus that colonized patients with AD produced an enzyme-ceramidase (Ohnishi et al., 1999). Since ceramides play a crucial role in the water-retaining in the stratum corneum, ceramidases action lead to the deficiency of ceramides molecules, which is associated with increasing trans-epidermal water loss and characteristic dry, cracked skin in patients with AD (Arikawa et al., 2002).

The level of antimicrobial peptides (AMPs) and host defense peptides (HDPs), produced by keratinocytes such as dermicidin, human $\beta$-defensins and cathelicidin-LL-37 are markedly reduced in $\mathrm{AD}$ skin, which also conduces to $S$. aureus colonization and infection (Ong et al., 2002; Roll et al., 2004). These peptides efficiently inhibit $S$. aureus growth (Niyonsaba et al., 2017). Th2 cytokines IL-4, IL-13, and IL-31, which are overexpressed in $\mathrm{AD}$ patients, inhibited the expression of the human $\beta$-defensins genes (hBD-2 and hBD-3). It is probably one of the factors that contribute to the proliferation of $S$. aureus, disturbance of microbiota composition and implication in the $\mathrm{AD}$ pathogenesis (Kanda and Watanabe, 2012).

Filaggrin (FLG) is an epidermal protein which is a part of the stratum corneum, the main barrier of the skin. Filaggrin is responsible for hydration, maintaining epidermal homeostasis, creating chemical, and structural barrier function (O'Regan and Irvine, 2008). The primary function is bonding keratin cytoskeleton in the process of keratinocytes maturation in the skin layer (Candi et al., 2005; Brown and McLean, 2012). Filaggrin can act as a scaffold for the connection of the lipids layers (O'Regan et al., 2008). As a result of filaggrin breakdown, pyrrolidone carboxylic acid (PCA) and urocanic acid (UCA) are formed, which are the composition of natural moisturizing factor (NMF) (Rawlings et al., 1994; O’Regan et al., 2008). This factor plays a crucial role in maintaining hydration of the stratum corneum and the appropriate $\mathrm{pH}$ of the skin (Rawlings et al., 1994; O'Regan et al., 2008). Nowadays, most studies proved that filaggrin loss-of-function mutations play an important role in the aggravation process in patients with $\mathrm{AD}$ (Brown and McLean, 2012). Reduced levels of filaggrin cause skin inflammation, resulting from the increasing penetration of allergens or irritants (Gruber et al., 2011). Furthermore, the levels of filaggrin and NMF are significantly decreased in AD patients (Brown and McLean, 2012). Also, PCA and UCA, filaggrin breakdown products have been in vitro shown to impact $S$. aureus cell density and growth rate (Miajlovic et al., 2010). Notably, in patients with a mutation in the filaggrin gene (FLG) increased $S$. aureus colonization was showed as compared to wild-type patients (Clausen et al., 2017).

In the skin, $\mathrm{pH}$ level plays a key role in maintaining the proper barrier function in the epidermis, protection against pathogens and control of the process of desquamation. The $\mathrm{pH}$ level of healthy skin is slightly acidic (4.0-6.0). Fatty acids-products of the phospholipid hydrolysis in sebum and sweat, maintain the low pH level (Chan and Mauro, 2011). There is an association 


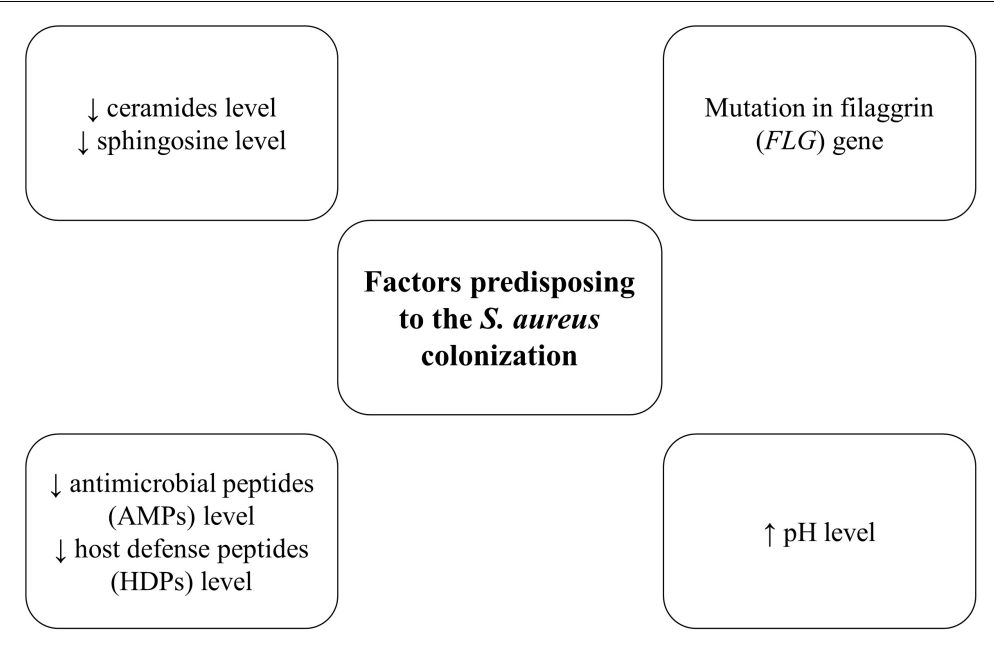

FIGURE 2 | Factors predisposing to the $S$. aureus colonization.

between the lower $\mathrm{pH}$ level and the reduced expression of proteins, in particular, those involved in adherence to the skin by S. aureus (e.g., protein $\mathrm{A}$, clumping factor $\mathrm{B}$, fibronectin-binding protein A) (Leung, 2013). Therefore, changes in the $\mathrm{pH}$ level toward more alkaline are one of the factors, facilitating S. aureus colonization and growth in AD patients (O'Regan and Irvine, 2008; Proksch et al., 2008; Clausen et al., 2019). The pH 7.08.0 has been shown optimal for $S$. aureus adhesion to human keratinocytes (Mempel et al., 1998).

\section{NO MAJOR S. AUREUS CLONES COULD BE ASSIGNED TO ISOLATES FROM AD PATIENTS}

Due to the frequent occurrence of $S$. aureus in patients with $\mathrm{AD}$, as well as the growing number of scientific reports on the mechanisms of immune response induction by specific virulence factors, a natural question arises whether there are selected $S$. aureus clones/types associated with the disease. A "gold standard" to determine the clonality of $S$. aureus strains, especially MRSA, is PFGE (Pulsed Field Gel Electrophoresis) (He et al., 2014). A specific "DNA fingerprint" for an individual clone is assigned to a specific pulsotype (e.g., A, B, C) (Golding et al., 2015). PFGE genotyping of $S$. aureus indicated that among the isolates from $\mathrm{AD}$ children, the most common pulsotype was $\mathrm{B}$ (48\%). In contrast, pulsotype A was the most frequent in the healthy control group (64\%) (Lo et al., 2010). However, Lomholt et al. (2005) indicated that 28 various S. aureus PFGE pulsotypes could be reported for $\mathrm{AD}$ patients.

With the application of MLST (multi-locus sequence typing), that is another useful method of microbial genotyping, Kim et al. (2009) revealed that sequence types ST188, ST1, ST5, and ST513 were the most frequently identified in the studied adolescent or adult patients with $\mathrm{AD}(19.4,13.9,11.1$, and $11.1 \%$, respectively). These data demonstrated the absence of prevailed genotype. Additionally, most of the detected lineages (especially
ST188 and ST1) were community-acquired strains in contrast to only a single ST5, which in Korea is associated with hospitalacquired strains.

Clausen et al. focused on the distribution of clonal complexes (CCs) determined based on spa typing among strains isolated from $\mathrm{AD}$ patients. As much as $92 \%$ of $S$. aureus isolates demonstrated identical spa types in three studied sites (nose, lesional, non-lesional skin). The most frequent spa types were t008, t084, t127, and t948 (Clausen et al., 2017). Different results were obtained by Kim et al. (2009), who identified t189 (19.4\%) as the most frequent type, followed by t127 (13.9\%), t164 (11.1\%), and t304 (8.1\%). These results confirm the observation on the heterogeneity of $S$. aureus strains isolated from $\mathrm{AD}$ patients.

Applying yet another typing method, namely, CC typing, Yeung et al. (2011) proved that in AD patients (adults and children), the most common clonal complex was CC45 (34 of S. aureus isolates out of 160), CC5 (23 isolates), CC15 (22 isolates), CC1 (21 isolates), CC30 (11 isolates), and CC398 (8 isolates). In another study by Rojo et al. (2014) two groups of patients were included as follows: AD patients $(n=32)$ and patients who suffered from other atopic diseases (asthma, allergic rhinitis or food allergy, $n=31$ ). Among $\mathrm{AD}$ patients, the most frequent CC was CC5 $(31.2 \%), \mathrm{CC} 15$ (18.7\%), CC30 (18.7\%), and CC45 (15.6\%), whereas CC30 mostly prevailed in the control group (48.3\%) (Rojo et al., 2014). Also, it was demonstrated that $95 \%$ of examined samples from $\mathrm{AD}$ patients belonged to the same clonal complex in three sampling sites (nose, lesional and non-lesional skin). Interestingly, the authors observed that $\mathrm{CC} 1$ was identified more frequently in patients with filaggrin mutations (Clausen et al., 2017). Similarly, Harkins et al. found in the inflamed skin of children with $\mathrm{AD}$ that the most prevalent clonal complex was CC1 (20\%), whereas CC30 (33\%), and CC45 (22\%) were predominantly detected in the anterior nares of healthy children (Harkins et al., 2018).

Temporal variation of CC types in S. aureus was observed in patients with mild to moderate $\mathrm{AD}$ where $52 \%$ of patients 
examined during follow up study were colonized by the same CC type. Interestingly, nearly half of the studied patients (48\%) demonstrated different CC types during the follow-up study, which correlated with increased SCORAD (Clausen et al., 2019).

Genetic variations present in S. aureus has been shown to influence clinical outcome in some essential diseases (Messina et al., 2016). The connection between clonal complex and infections was documented for CC8 associated with sepsis, CC30 associated with endocarditis or CC398 associated with nasal carriage and bone and joint infection (Nienaber et al., 2011; Spaulding et al., 2012; Valour et al., 2014). The distribution of staphylococcal clonal complexes in $\mathrm{AD}$ patients that has been analyzed throughout the recent years points for great heterogeneity, and no specific clone/clones prevailed in this group of patients. Moreover, observations proved that populations of $S$. aureus isolated from $\mathrm{AD}$ patients are very clonal, and that characteristic virulence factor variants that have been shown to contribute to $\mathrm{AD}$ may occur in different clonal lineages. This further means that this is rather unlikely to characterize specific S. aureus lineages associated with $\mathrm{AD}$ and disease severity, at least based on traditional typing methods (Kim et al., 2009; Yeung et al., 2011; Rojo et al., 2014; Clausen et al., 2017). The only example of a correlation between S. aureus genetic background and $\mathrm{AD}$ was the one found by Clausen et al., where CC1 clone was the most commonly detected among AD patients (22\% of all colonized patients) and significantly more prevalent in filaggrin mutation carriers (Clausen et al., 2018). Nevertheless, considering the above observation and the dynamic evolution of the $S$. aureus species based on the survival of only those populations that can survive in given conditions (e.g., in a defective atopic skin), the existence of $\mathrm{AD}$-specific genotype(s) cannot be excluded. S. aureus genetic variations that might contribute to a particular clinical outcome (like infection of atopic skin) might be present at different levels: clonal, gene, or at the level of gene polymorphisms. Therefore, detailed knowledge about the bacterial genetic variation is needed to understand better the role of $S$. aureus in the pathogenesis of $\mathrm{AD}$.

\section{A NEW CONCEPT OF STRAIN-SPECIFIC COLONIZATION OF S. AUREUS IN AD}

Traditional genotyping methods allow the differentiation of staphylococcal isolates from $\mathrm{AD}$ patients. These methods, however, have their resolution limitations, which did not allow identification of specific genetic features of AD-derived $S$. aureus. At the same time, there are functional differences manifested by altered immune responses in the skin between $\mathrm{AD} S$. aureus strains vs. non-AD $S$. aureus strains. It was observed that only $\mathrm{AD}$-derived $S$. aureus strains altered $\mathrm{T}$ cell response via Langerhans cells (Iwamoto et al., 2017), and only $\mathrm{AD}$-derived strains accumulated in lysosomes and induced IL-1 $\alpha$ production via Toll-like receptor 9 (Moriwaki et al., 2019). The observed differences have been attributed to surface proteins (Iwamoto et al., 2017; Moriwaki et al., 2019). In line with those reports, $S$. aureus isolated from $\mathrm{AD}$ but not from healthy carriers induced strong inflammation in the mouse model of AD (Byrd et al., 2017). Whole-genome sequencing of AD-derived S. aureus revealed genes coding for proteins associated with infection, carotenoid production, or $\beta$-lactam resistance to be associated with $\mathrm{AD}$ colonization (Byrd et al., 2017). Analyzing $A D$ microbiome suggests that $A D$ patients may be preferentially colonized by those $S$. aureus strains that can synthesize tryptophan (Fyhrquist et al., 2019). It was experimentally shown, however, that tryptophan metabolites on atopic skin are significantly reduced, and therefore strains that do not require exogenous tryptophan for growth may be preferred (Yu et al., 2019). The concept of specific S. aureus isolates that have a more significant potential to colonize atopic skin or induce an immune effect in $\mathrm{AD}$ patients has developed significantly in recent years. Mainly due to the results of studies linking the production of $S$. aureus $\delta$-toxin with allergic skin diseases (Nakamura et al., 2013).

Staphylococcus aureus once established on the skin, promotes inflammation through multiple pathways. Recent work from several laboratories has advanced our understanding of how the skin colonization of $S$. aureus promotes inflammatory skin diseases. The general overview of the pathways involved in S. aureus and its virulence factors contribution to $\mathrm{AD}$ is presented in Figure 3.

It has been documented that $S$. aureus is able not only to colonize the surface of the skin, but it also penetrates the dermis, where the bacterium can come into direct contact with immune cells and stimulate the production of proinflammatory cytokines (Nakatsuji et al., 2016). S. aureus produces a range of potent virulence factors that appeared to play a crucial role in the inflammation process driven by the bacterium, e.g., PSMs (phenol soluble modulins), proteases (aureolysin, V8 protease, SspA serine protease, ScpA cysteine protease), superantigens (staphylococcal enterotoxin A, B, TSST-1). PSM $\alpha$ has been shown to induce expression of cytokines in keratinocyte cell lines as well as in a mouse model of $\mathrm{AD}$ via lysis of keratinocytes, which led to the release of inflammatory cytokines (Syed et al., 2015). Another PSM representative, namely $\delta$-toxin was identified in abundant amounts in culture supernatants of $S$. aureus isolated from the skin of $\mathrm{AD}$ patients and was shown to be a potent inducer of mast cells degranulation suggesting for the first time a link between $S$. aureus colonization and allergic skin diseases (Nakamura et al., 2013). In this case, the mechanism of action was different from other PSMs, as $\delta$-toxin (PSM $\gamma$ ) did not cause cell lysis but rather induced signaling pathway leading to increased IgE, IL-4 levels (Figure 3). PSMs are critical for the induction of IL-17 producing cells, namely $\gamma \delta$ Tcells or ILC3 (type 3 lymphoid cells), which are mediators of skin inflammation in response to S. aureus (Nakagawa et al., 2017). Depending on the depth bacteria can reach in the skin-epidermis vs. dermis, different host response can be elicited. Epicutaneous exposure of $S$. aureus promotes inflammation via IL-36, produced mostly by keratinocytes, whereas intradermal challenge promotes IL- $1 \beta$ induction of inflammation (Liu et al., 2017). The penetration depth has been shown to critically depend on an important group of virulence factors produced by the bacterium, namely serine proteases (Nakatsuji et al., 2016). 


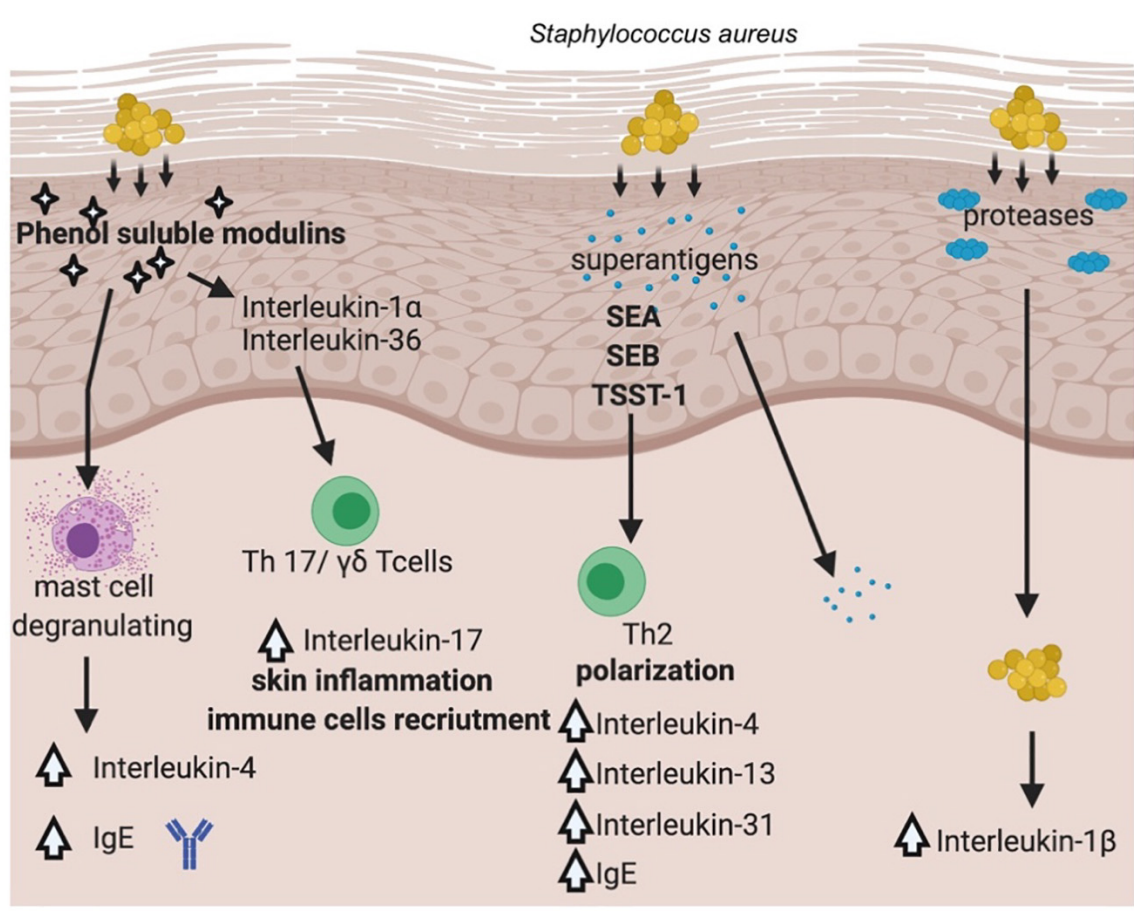

FIGURE 3 | Pathways involved in S. aureus' virulence factors contribution to AD. (Created with BioRender).

Toll-like receptors (TLRs), recognizing various bacterial antigens (e.g., cell wall components), transduce a signal through MyD88 (Myeloid differentiation primary response gene-88) signaling pathway that leads to activation of NFKB transcription factor and production of proinflammatory cytokines (Kuo et al., 2013). Recently, MyD88-dependent signaling was demonstrated a critical pathway activated in response to staphylococcal virulence factors-PSM $\alpha$ (Liu et al., 2017) and SEB (Faßbender et al., 2017). SEB is one of the best-studied enterotoxins in the context of inflammation in AD patients, next to SEA and TSST-1. However, in recent years, experimental data on other members of this group of virulence factors have emerged, expanding our understanding of the mechanisms linking S. aureus and AD (Aziz et al., 2019; Orfali et al., 2019). A transcriptomic approach to study keratinocyte response to SEB or TSST-1 has been shown to up- or downregulate more than 3,000 genes, confirming a previously proposed signaling pathway through CD40 receptor (Schlievert et al., 2020).

These phenomena require even more detailed knowledge, but it turns out that $S$. aureus may play a vital role in the development of $\mathrm{AD}$ in a strain-specific manner. The experimental data trying to provide an answer to a question whether $S$. aureus causes $\mathrm{AD}$ or its increased survival on $\mathrm{AD}$ skin is a consequence of the disease is only starting to emerge. More and more puzzles add up to a complete picture that may soon allow us to understand better the molecular mechanism of a complex relation between $S$. aureus and $\mathrm{AD}$ (Geoghegan et al., 2018).

\section{AN AMBIGUITY OF STAPHYLOCOCCAL ENTEROTOXINS (SES) IN ATOPIC DERMATITIS}

From the vast repertoire of $S$. aureus' virulence factors, we will focus on a specific group-enterotoxins, which $S$. aureus produces dozens of varieties.

The pyrogenic toxin superantigen (PTSA) family is the group of staphylococcal toxins that includes the following clusters: staphylococcal enterotoxins (SEs), staphylococcal enterotoxinlike toxins (SEls), and toxic shock syndrome toxin (TSST-1). The nomenclature distinguished SEs (SEA, SEB, SEC, SED, SEE) from SEls (SElG, SElH, SElJ, SElK, SElL, SElM, SEIN, SElO, SElP, and SElQ) is based on their causing (SEs) or not causing (SEls) emesis in humans (Figure 4; Lina et al., 2004). Staphylococcal enterotoxins (SEs) are known as bacterial virulence factors that contribute to the development of many human diseases, including toxic shock syndrome or food poisoning (Harris et al., 1993; Balaban and Rasooly, 2000; Ortega et al., 2010; Pinchuk et al., 2010). Many authors have indicated a role for SEs in the course of $\mathrm{AD}$ by acting as factors aggravating and exacerbating the inflammation of AD skin (Bunikowski et al., 2000; Taskapan and Kumar, 2000; Yarwood et al., 2000; Zollner et al., 2000). Moreover, there are indications for the causative role of SEs in the course of AD.

The most common feature of SEs is that they possess superantigenic properties (Spaulding et al., 2013). Superantigens (SAgs) can bind as intact proteins to the T-cell antigen receptor (TCR) and the major histocompatibility complex II 


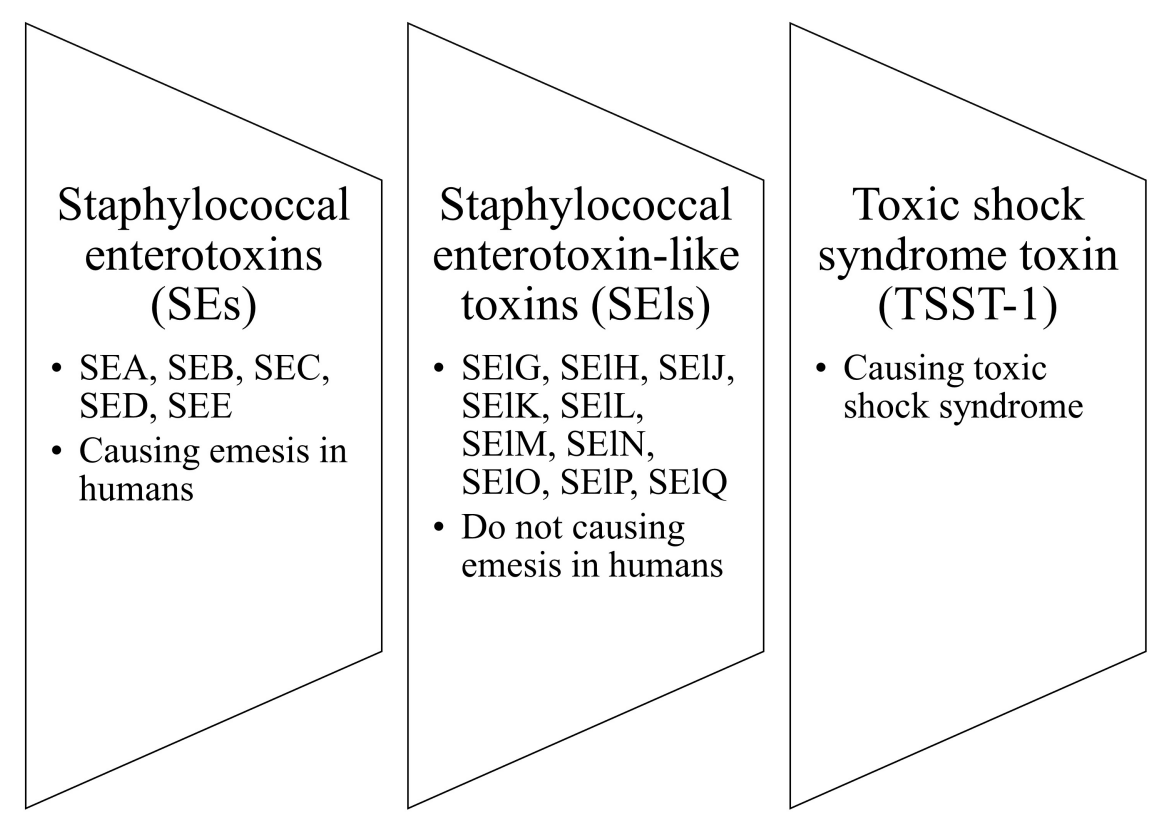

FIGURE 4 | Three clusters of staphylococcal toxins.

(MHC II) outside their binding site (Fink et al., 1986) thus, stimulating massive proliferation of nonspecific $\mathrm{T}$ cells and release of proinflammatory cytokines (Harris et al., 1993; Holtfreter et al., 2006).

Because of interest in SEs as an aggravating factor in $\mathrm{AD}$, their distribution in $\mathrm{AD}$-derived S. aureus isolates was a matter of deep interest. The main question researchers asked concerned a potential pattern (universal vs. specific) of SEs presence in ADderived S. aureus. It has been known that $54-71.25 \%$ of S. aureus isolates indicated the presence of SE genes among AD patients (Mempel et al., 2003; Nada et al., 2012). Furthermore, a metaanalysis of 95 studies indicated that the rate of toxins producing S. aureus on the lesional skin fluctuated between 31.5 and $80 \%$ (Totté et al., 2016), and was higher than in healthy controls. The distribution of SE genes, however, varied from one studied population to another: in Korean population sea and tsst-1 were the most common toxin genes (Kim et al., 2009; Na et al., 2012); in Germany, whereas one study showed that seb (38\%) and tsst$1(23 \%)$ toxin genes were the most prevalent, and sea was not detected (Zollner et al., 2000), other revealed that sea and sed were most commonly detected (Breuer et al., 2002). All SEs production patterns from adult $\mathrm{AD}$ patients are summarized in Table 2. In the studies of Taiwanese children with AD, the most frequent toxin gene was seb (87\%), followed by $\sec (9 \%)$, tsst-1 (9\%), sea (4\%), seg/sei (4\%), and seh (4\%). The sed toxin gene was not identified in atopic children, whereas it was predominant in healthy children. It is worth to mention, however, that only the MRSA population was studied (Lo et al., 2010). In England, the most prevalent toxins were sec (25\% from the skin; $11 \%$ from the nose), seg ( $21 \%$ from the skin; $17 \%$ from the nose), and sei ( $21 \%$ from the skin; $17 \%$ from the nose). Most cases represented the same strains in the nose and skin (Arkwright et al., 2001). In
Spain, hla and $h l g / h l g V(26,100 \%), h l b(17,65.5 \%)$, lukDE (25, $96.1 \%)$, tsst-1 (13, 50\%), aur (11,42.3\%), cna (10,38.5\%), eta (4, $15.4 \%)$, and $\sec (2,7.7 \%)$ were the virulence genes detected in cutaneous isolates of children with AD (Gilaberte et al., 2015). The observed variations in SEs distribution patterns in different research and different $\mathrm{AD}$ populations indicate geographical dependence. All SEs production patterns from AD children are summarized in Table 1.

Interestingly, in some studies based on populations of both children and adults, the most frequently detected genes were not classical toxins found in $38 \%$ of $\mathrm{AD}$-derived strains, but enterotoxin gene cluster $(e g c)$, which consisted of seg, sei, sek, sem, sen, and seo (Mempel et al., 2003). Studies on the AD cohort from Singapore indicated that the most prevalent SEs were seb (42\%), egc (32\%), and seh (29\%). Interestingly, Chiu et al. proposed that patients with a moderate type of $\mathrm{AD}$ were more likely to be colonized by S. aureus possessing staphylococcal enterotoxin B (seb) than patients with a severe type of AD (Chiu et al., 2009). Nevertheless, another distribution pattern of toxins was observed in Portuguese $\mathrm{AD}$ patients, where $76 \%$ of the examined S. aureus strains were SE-positive, mainly for SEls: sel-m and sel-n (71.4\%), followed by sel-o and seg (66.7\%) and sea and sel-l were less frequent (29\% and 33\%, respectively) (Soares et al., 2013). In the Egyptian cohort, the most prevalent gene from the S. aureus strains isolated from the lesional skin of $\mathrm{AD}$ patients was seb, followed by sec and tsst-1, sea and sed (Nada et al., 2012). All SEs gene presence patterns from the mixed groups of $\mathrm{AD}$ patients are summarized in Table 3.

It is not uncommon that $\mathrm{AD}$-derived strains of $S$. aureus can produce more than a single enterotoxin (Schlievert et al., 2008; $\mathrm{Na}$ et al., 2012), and at significantly higher amounts (Schlievert et al., 2008). The overall picture is even more complex when 
TABLE 3 | The distribution of S. aureus colonization and toxins production in combined groups of AD patients (both children and adults).

\begin{tabular}{|c|c|c|c|c|}
\hline References & Examined groups & Sites of isolation & $\begin{array}{l}\text { Colonization of staphylococcus } \\
\text { aureus }\end{array}$ & Toxins production \\
\hline $\begin{array}{l}\text { Leung et al. (1993) } \\
\text { United States }\end{array}$ & $\begin{array}{l}\text { Patients with AD } \\
(n=56) \\
\text { Four groups of control } \\
\text { patients: } \\
\text { - healthy, non-atopic } \\
\text { patients }(n=15) \\
\text { - patients with psoriasis } \\
(n=16) \\
\text { - patients with respiratory } \\
\text { allergy: allergic rhinitis } \\
\text { and asthma }(n=10) \\
\text { - patients with HIE } \\
\text { syndrome }(n=7)\end{array}$ & AD lesional skin & No data & $\begin{array}{l}\text { AD patients sea: } 7(29 \%), \text { seb: } \\
8(33 \%), \text { sec: } 0(0 \%), \text { sed: } 1 \\
(4 \%), \text { tsst-1: } 7(29 \%)\end{array}$ \\
\hline $\begin{array}{l}\text { Nomura et al. (1999) } \\
\text { Japan }\end{array}$ & $\begin{array}{l}\text { Patients with } A D \\
\text { (aged } 1-22 \text { years } \\
n=39 \text { ) }\end{array}$ & $\begin{array}{l}\text { Exudative dermatitis } \\
\text { Dry dermatitis } \\
\text { Normal skin }\end{array}$ & $\begin{array}{l}37 \text { of } 39 \text { patients (95\%) were colonized } \\
\text { with S. aureus on the skin }\end{array}$ & $\begin{array}{l}21 \text { of } 37 \text { S. aureus isolates } \\
\text { (56.76\%) were produced } \\
\text { exotoxins } \\
\text { sea: } 2(5.1 \%) \text {, seb: } 13(33.3 \%) \text {, } \\
\text { sec: } 1(2.6 \%) \text {, sed: } 1(2.6 \%) \text {, } \\
\text { tsst-1: } 1(2.6 \%), \text { sea }+ \text { seb: } 1 \\
(2.6 \%), \text { seb+sec: } 1(2.6 \%), \\
\text { seb+tsst-1: } 1(2.6 \%)\end{array}$ \\
\hline $\begin{array}{l}\text { Matsui et al. (2000) } \\
\text { Japan }\end{array}$ & $\begin{array}{l}\text { Patients with AD (aged } \\
7-45, n=26) \\
\text { Healthy group ( } n=49)\end{array}$ & $\begin{array}{l}\text { Lesional } \\
\text { Non-lesional skin (face, } \\
\text { neck or arm) }\end{array}$ & $\begin{array}{l}96.2 \% \text { of } A D \text { patients on the lesional } \\
\text { skin } \\
30.8 \% \text { of } A D \text { patients on the } \\
\text { non-lesional skin } \\
10.2 \% \text { of healthy control subjects on } \\
\text { the non-lesional skin }\end{array}$ & $\begin{array}{l}\text { Lesional skin in AD patients } \\
(40 \%, 10 / 25 \text { patients) } \\
\text { sea }(4 / 10,40 \%), \text { seb }(1 / 10, \\
10 \%), \text { sec }(5 / 10,50 \%), \text { sed } \\
(0 / 10,0 \%), \text { see }(0 / 10,0 \%), \\
\text { tsst-1 }(3 / 10,30 \%) \\
\text { Non-lesional skin in AD patients } \\
\text { (37.5\%, 3/8 patients) } \\
\text { sea }(0 / 8,0 \%), \text { seb }(1 / 8, \\
12.5 \%), \text { sec }(1 / 8,12.5 \%), \text { sed } \\
(0 / 8,0 \%), \text { see }(0 / 8,0 \%), \text { tsst-1 } \\
(3 / 8,37.5 \%) \\
\text { Healthy control group }(40 \%, \\
2 / 5 \text { patients) } \\
\text { sea }(2 / 5,40 \%), \text { seb }(0 / 5,0 \%), \\
\text { sec }(0 / 5,0 \%), \text { sed }(0 / 5,0 \%), \\
\text { see }(0 / 5,0 \%), \text { tsst- } 1(1 / 5,20 \%)\end{array}$ \\
\hline $\begin{array}{l}\text { Yagi et al. (2004) } \\
\text { Japan }\end{array}$ & $\begin{array}{l}\text { Patients with AD } \\
\text { ( } n=100) \text { included: } \\
\text { - infants }(n=55) \\
\text { - children }(n=28) \\
\text { - adults }(n=17)\end{array}$ & No data & No data & $\begin{array}{l}81 \text { isolates (81\%) produce } \\
\text { at least one toxin } \\
\text { - nasal cavity: } 57(70.4 \%) \\
\text { - non-lesional area: } 33(40.7 \%) \\
\text { - dry-lesional area: } 50(61.7 \%) \\
\text { - exudative-lesional area: } \\
\text { 61(75.3\%) } \\
\text { sea: } 22(27.2 \%) \text {, seb: } 44 \\
(54.3 \%), \\
\text { sec: } 22(27.2 \%), \text { sed: } 4(4.9 \%) \text {, } \\
\text { tsst-1: } 13(16.0 \%)\end{array}$ \\
\hline
\end{tabular}


TABLE 3 | Continued

\begin{tabular}{|c|c|c|c|c|}
\hline $\begin{array}{l}\text { Tomi et al. (2005) } \\
\text { Austria }\end{array}$ & $\begin{array}{l}\text { Patients with } A D(3 \\
\text { months-60 years, } \\
n=25) \\
\text { Healthy control }(n=25)\end{array}$ & $\begin{array}{l}\text { Lesional skin or volar } \\
\text { site of the elbow } \\
\text { Nares area }\end{array}$ & $\begin{array}{l}\text { Atopic dermatitis patients 22/25 } \\
\text { patients (88\%) } \\
\text { - skin only: } 0(0 \%) \\
\text { - nares only: } 7(32 \%) \\
\text { - skin and nares: } 15(68 \%) \\
\text { Healthy control 3/25 patients (12\%) } \\
\text { - skin only: } 1(33 \%) \\
\text { - nares only: } 2(67 \%) \\
\text { - skin and nares: } 0(0 \%)\end{array}$ & $\begin{array}{l}\text { Atopic dermatitis patients } \\
\text { sec }>\text { seb }>\text { sea+sed } \\
\text { Healthy control None of the } \\
\text { strains were toxigenic }\end{array}$ \\
\hline $\begin{array}{l}\text { Chiu et al. (2009) } \\
\text { Singapore }\end{array}$ & $\begin{array}{l}\text { Children and adults } \\
\text { with AD, 2-21 years old } \\
(n=34)\end{array}$ & $\begin{array}{l}\text { Nasal swabs } \\
\text { Affected skin }\end{array}$ & $\begin{array}{l}91 \% \text { were colonized with S. aureus } \\
\text { (31/34 of isolates) } \\
85 \% \text { were colonized both in the skin } \\
\text { and in the nose ( } 29 / 34 \text { S. aureus } \\
\text { strains) }\end{array}$ & $\begin{array}{l}\text { sea: } 6 \text { (17.6\%), seb: } 13 \\
\text { (38.2\%), sec: } 4 \text { (11.8\%), sed: } 3 \\
\text { (8.8\%), egc: } 10 \text { (29.4\%), seh: } 9 \\
(26.5 \%), \text { sek: } 5 \text { (14.7\%), sel: } 2 \\
(5.9 \%), \text { tsst-1: } 1 \text { (2.9\%) }\end{array}$ \\
\hline $\begin{array}{l}\text { Na et al. (2012) } \\
\text { Korea }\end{array}$ & $\begin{array}{l}\text { Patients with AD } \\
(n=39) \\
1-40 \text { years } \\
\text { Healthy control }(n=40)\end{array}$ & $\begin{array}{l}\text { Antecubital area } \\
\text { Popliteal fossa } \\
\text { Nasal mucosa }\end{array}$ & $\begin{array}{l}\text { Atopic dermatitis patients: } \\
\text { - antecubital area: } 10(25.6 \%) \\
\text { - popliteal fossa: } 14(35.8 \%) \\
\text { - nasal mucosa: } 18(46.1 \%) \\
\text { - overall colonization: } 25(64.1 \%) \\
\text { Healthy control: } \\
\text { - antecubital area: } 1(2.5 \%) \\
\text { - popliteal fossa: } 2(5 \%) \\
\text { - nasal mucosa: } 7(17.5 \%) \\
\text { - overall colonization: } 8(20 \%)\end{array}$ & $\begin{array}{l}\text { sea: } 52.6 \% \\
\text { sea+tsst-1: } 42.1 \% \\
\text { tsst-1: } 5.3 \%\end{array}$ \\
\hline $\begin{array}{l}\text { Nada et al. (2012) } \\
\text { Egypt }\end{array}$ & $\begin{array}{l}\text { AD patients }(5-26 \\
\text { years, } n=30) \\
\text { Healthy control group } \\
(n=30)\end{array}$ & From different lesions & $\begin{array}{l}\text { AD patients } 26 \text { ( } 87 \%) \text { patients were } \\
\text { colonized by S. aureus }\end{array}$ & $\begin{array}{l}14 \text { isolates ( } 54 \%) \text { of } 26 \\
\text { S. aureus strains produced } \\
\text { exotoxins with superantigenic } \\
\text { properties } \\
\text { sea: } 1 \text {, seb: } 8 \text {, sec: } 4 \text {, } \\
\text { sed: } 1 \text {, tsst- } 1: 4\end{array}$ \\
\hline $\begin{array}{l}\text { Soares et al. (2013) } \\
\text { Portugal }\end{array}$ & $\begin{array}{l}\text { AD patients }(3-35 \\
\text { years, } n=9) \\
\text { Healthy controls } \\
(n=24)\end{array}$ & $\begin{array}{l}\text { AD patients } \\
\text { Samples were collected } \\
\text { from the antecubital } \\
\text { and popliteal crease } \\
\text { Healthy controls } \\
\text { Samples were collected } \\
\text { from antecubital crease }\end{array}$ & No data & $\begin{array}{l}\text { AD patients ( } 21 \text { S. aureus } \\
\text { strains were tested) - } \\
16(76 \%) \text { were toxigenic } \\
\text { sea: } 6(29 \%) \\
\text { seg: } 14(66.7 \%) \\
\text { Other classical toxins (seb-see) } \\
\text { were not detected. }\end{array}$ \\
\hline $\begin{array}{l}\text { Rojo et al. (2014) } \\
\text { Spain }\end{array}$ & $\begin{array}{l}\text { Patients with AD and } \\
\text { colonized by } S \text {. aureus } \\
\text { on lesional skin ( } n=32 \text { ) } \\
\text { Controls-atopic } \\
\text { patients with active } \\
\text { allergic disease } \\
\text { (asthma, food alergy or } \\
\text { rhinitis) and with } \\
\text { S. aureus isolated from } \\
\text { nose }(n=31)\end{array}$ & $\begin{array}{l}\text { Skin area } \\
\text { Nasal area } \\
\text { Inguinal area } \\
\text { Perianal area }\end{array}$ & $\begin{array}{l}\text { All of the patients included in the study } \\
\text { were colonized by S. aureus }\end{array}$ & $\begin{array}{l}\text { AD patients sea: } 14(43.7 \%), \\
\text { seb: } 0 \\
\text { sec: } 7(21.8 \%), \text { see: } 0 \\
\text { tsst-1: } 4(12.5 \%) \\
\text { Atopic controls sea: } 14 \\
\text { (45.1\%), seb: } 3 \text { (9.6\%), } \\
\text { sec: } 2(6.4 \%), \text { see: } 0 \\
\text { tsst-1: } 15(48.4 \%)\end{array}$ \\
\hline $\begin{array}{l}\text { Merriman et al. (2016) } \\
\text { United States }\end{array}$ & $\begin{array}{l}\text { AD patients }(6-37 \\
\text { years, } n=103)\end{array}$ & Lesional AD skin & No data & $\begin{array}{l}\text { sea: } 7 \text { (6.8\%), seb: } 6(5.8 \%) \text {, } \\
\text { sec: } 11(11 \%) \text {, sed: } 16(16 \%) \text {, } \\
\text { tsst-1: } 10(9.7 \%)\end{array}$ \\
\hline
\end{tabular}

SE-specific IgE antibodies are considered. These were detected in $\mathrm{AD}$ patients even if the genes coding for particular SEs were absent in S. aureus. Furthermore, specific anti-SE IgE was not detected, albeit toxigenic $S$. aureus was isolated from an $\mathrm{AD}$ patient (Rojo et al., 2014). Such observation indicated temporal changes in the colonization of $\mathrm{AD}$ patients with $S$. aureus (Merriman et al., 2016).

Similarly to the association between the presence of $S$. aureus and $\mathrm{AD}$ severity, some authors have also observed that SEproducing $S$. aureus is more associated to $\mathrm{AD}$ severity than
SE non-producing S. aureus (Bunikowski et al., 2000; Zollner et al., 2000; Breuer et al., 2002; Tomi et al., 2005). On the contrary, others found no relationship between superantigens production and the SCORAD index (Mempel et al., 2003; Rojo et al., 2014). These differences may result from various genes repertoire studied by different authors, e.g., Mempel et al. (2003) and Rojo et al. (2014) included enterotoxins rarely studied by others (see, seh, sej, and egc). Rojo et al. (2014) proved that $65.6 \%$ of S. aureus strains isolated from AD patients carried genes encoding staphylococcal enterotoxin-like proteins, which 
function is still poorly understood. Several factors, including estimation of the skin inflammation, the number of patients in the studied groups, or methodological variations in SEs detection (molecular vs. immunological), could be responsible for these divergent observations. In fact one study found that low serum vitamin D levels have been associated with the presence of virulence factors tsst-1, eta, can, aur, and sec (Gilaberte et al., 2015). Based on the available literature data and the different methodologies used in the studies, it can be concluded that there is a divergent distribution rather than the specific pattern of enterotoxins producing strains among patients with $\mathrm{AD}$.

\section{METHODOLOGY PROBLEMS CONTRIBUTING TO THE OBSERVED DIVERGENT DISTRIBUTION OF SES}

The presented review attempts to explain possible gaps that may lead to ambiguous results and observations as to whether S. aureus isolated from AD patients has any specific features. Among these ambiguities (i) differences in sampling, (ii) isolations site, (iii) characteristics of the population studied, (iv) selection of the control population, and finally (v) the diagnostic method used to detect $S$. aureus and its virulence factors, can be mentioned.

Most researchers used swabs from the different site of $\mathrm{AD}$ patients (anterior nares, lesional, and non-lesional skin), while others used contact plate method (Bunikowski et al., 2000; Matsui et al., 2000; Kim et al., 2009). The contact plate method is mainly intended for environmental monitoring of surfaces and is not routinely used in dermatology. The advantage of using a contact plate is a large sampling area compared to the swab method. This allows for reliable quantitative results to be obtained. The second difference is that the contact plate method is swift-sampling and inoculation are performed in one step. However, this method does not allow to sample the anterior nares. On the contrary, the swab method is most commonly used but requires inoculation on agar plates, and sampling covers only a small area of skin. As a result, significant changes in bacterial flora can be overlooked. There is currently no literature evidence comparing the results obtained from these two techniques - swab method and contact plate method in $\mathrm{AD}$ patients.

Another problem is the site of bacterial isolation. Most often, samples are taken from AD patients skin, either lesional or nonlesional, or both. On the other hand, anterior nares are not included in many studies, while the nose has been proven to be an important reservoir for $S$. aureus in patients with $\mathrm{AD}$. Also, S. aureus can be easily diffused on the skin area due to autotransmission (Breuer et al., 2002). Some studies deserve special attention because they are based on samples of $S$. aureus derived from the skin (lesional and non-lesional) and anterior nares, which allows a better understanding of the distribution of $S$. aureus and its toxins from various sites of isolation (Breuer et al., 2002; Pascolini et al., 2011; Clausen et al., 2019).

The third important issue is the selection of the studied population. For example, some authors based their research on the mix groups of $\mathrm{AD}$ patients, that included both children and adults (Matsui et al., 2000; Zollner et al., 2000; Chiu et al., 2009; Nada et al., 2012). It is worth mentioning that presenting results from the mixed group of $\mathrm{AD}$ patients may produce different results as if only specific age groups were considered. This is because the course of $\mathrm{AD}$ is divided into three phases: infantile, childhood, and adulthood. These phases differ in the location of skin lesions, which may affect the results regarding the distribution of S. aureus (Nutten, 2015). Also, aging-related changes in bacterial flora and the distribution of $S$. aureus toxin genes were observed. As an example, regarding the distribution of the seb toxin gene, in infants, the seb gene was detected in $46.5 \%$ of $S$. aureus strains, in children in $58.3 \%$, and adults in $71.4 \%$ strains (Yagi et al., 2004). It should be emphasized here that the number of the studied groups varies considerably from study to study, and often the groups are small, the majority include less than $50 \mathrm{AD}$ patients. This approach may not allow general conclusions to be drawn about the variability of $S$. aureus toxin genes distribution across the entire population.

The problem with the control group is also important and might affect the overall picture of the studied phenomenon. Some studies have omitted the control group (Arkwright et al., 2001; Breuer et al., 2002; Mempel et al., 2003; Kim et al., 2009; Merriman et al., 2016), while the vast majority included healthy, non-atopic, not having accompanying allergic diseases patients, which is the most reasonable approach (Bunikowski et al., 2000; Matsui et al., 2000; Yagi et al., 2004; Pascolini et al., 2011; Nada et al., 2012). However, patients with urticaria, healthy $S$. aureus vagina isolates, or atopic patients with active allergic diseases were also examined as control populations (Schlievert et al., 2008; Park et al., 2013; Rojo et al., 2014). It may be more difficult to observe significant differences or characteristic trends based on the distribution of $S$. aureus toxins in patients with atopic dermatitis and a group of patients with other allergic diseases.

The last problem is the use of various diagnostic methods to detect the studied strain of $S$. aureus and its virulence factors, e.g., staphylococcal enterotoxin genes. The most popular and the most commonly used method for the identification the S. aureus toxin genes is PCR (polymerase chain reaction). However, many publications do not contain information on positive and negative controls used in PCR reactions (Yagi et al., 2004; $\mathrm{Na}$ et al., 2012). It was uncertain whether the PCR reaction was carried out following approved diagnostic standards. Only a few published papers clearly described the positive controls used in the study (Arkwright et al., 2001; Nada et al., 2012; Merriman et al., 2016). In addition to the molecular method, immunoassay was also used. To detect $S$. aureus enterotoxins, the technique of reversed passive latex agglutination technique (RPLA) was used, which gives semi-quantitative results (Bunikowski et al., 2000; Breuer et al., 2002; Lomholt et al., 2005). As recommended by the Thermo Scientific ${ }^{\mathrm{TM}}$, this technique is useful for detecting enterotoxins in a wide variety of foods.

In order to obtain comparable results, the steps should be standardized, from sample preparation to selection of studied groups to a uniform methodology. A universal methodology should be created that can be used to compare results among different laboratories and countries. 


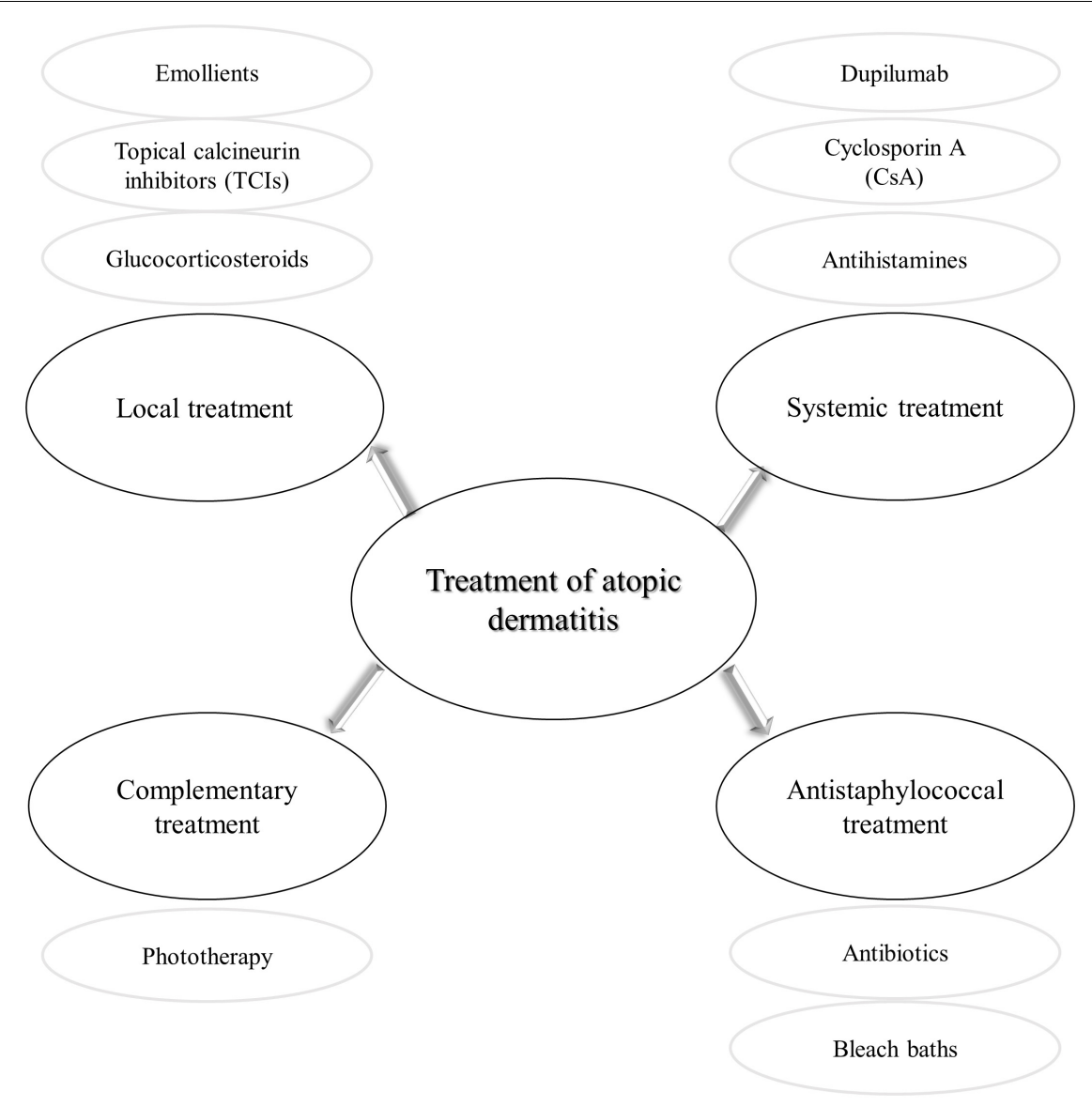

FIGURE 5 | Different types of atopic dermatitis treatment.

\section{TREATMENT OF ATOPIC DERMATITIS}

The treatment of $\mathrm{AD}$ given its multifactorial pathogenesis and chronic characteristics is challenging. It consists of anti-inflammatory and symptomatic therapy, followed by strengthening the damaged natural layers of skin (Figure 5). Local treatment is based on the application of corticosteroids or calcineurin inhibitors, as well as emollients. Topical glucocorticosteroids are the first-line anti-inflammatory treatment in AD (Darsow et al., 2005). These drugs are not free from side effects, e.g., atrophy, purpura, dyspigmentation (Weidinger et al., 2017). As a result of repeated administration of glucocorticosteroids, the response to these compounds is reduced (Brazzini and Pimpinelli, 2002). Anti-inflammatory therapy, free of steroids enables topical calcineurin inhibitors (TCIs), e.g., pimecrolimus (ASM 981/Elidel) and tacrolimus (FK-506/Protopic) (Hanifin et al., 2004; Akdis et al., 2006). Since 2002, an ointment containing tacrolimus has been available in the European Union countries (Rustin, 2007). The central role of TCIs is inhibition of $\mathrm{T}$ lymphocytes activation and thus release the inflammatory cytokines (Hanifin et al., 2004). In order to restore the proper barrier function of the damaged skin, it is essential to maintain the disturbed hydration of the epidermis.
To this end, moisturizers containing emollients and humectants have been shown to reduce itching, flares and even reduce the necessity of anti-inflammatory drugs (Zuuren et al., 2017). More recently, a targeted topical therapy based on the use of crisaborole $2 \%$ ointment has been approved by the FDA to treat children and adults with mild to moderate AD. Crisabolol action is based on inhibiting intracellular enzyme phosphodiesterase 4 to regulate inflammation (Eichenfield et al., 2017; Woo and Kuzel, 2019). As for the topical types of treatment, phototherapy has been considered an option, based on narrow-band UVB or UVA ultraviolet light (Garritsen et al., 2014). This type of treatment is not free from adverse effects, including photodamage or in longterm effects skin carcinogenesis mainly due to the application of UV light (Rodenbeck et al., 2016).

In exceptional cases, cyclosporine A (CsA), methotrexate, azathioprine are used systemically. CsA is a calcineurin inhibitor approved for severe $\mathrm{AD}$ cases. Unfortunately, its use is limited (approved only in some EU countries, for patients > 16 y.o.), due to a wide range of side effects, e.g., hypertension, gastrointestinal discomfort, liver dysfunction, and impairment of renal function (with increasing creatinine and urea level in serum) (Hanifin et al., 2004; Akdis et al., 2006; Nowicki et al., 2015). More recently, therapy has been developed that targets 
the dominant mechanism involved in $\mathrm{AD}$, namely activation of Th2 immune pathways. Dupilumab, a fully human monoclonal antibody targets interleukin 4 receptor alpha (IL-4R $\alpha)$ that inhibits IL-4 and IL-13 signaling (Simpson et al., 2016; Worm et al., 2020). Another group of modern drugs that seem to be very promising in AD treatment are inhibitors of JAK/STAT signaling pathway, that is responsible for controlling cytokine production and regulation (Schwartz et al., 2017). Some representative of this group of drugs, baricitinib, abrocitinib, and upadacitinib are currently in clinical trials (phase 3 completed) with a positive outcome in studied populations (Ferreira et al., 2020; Simpson et al., 2020a,b).

\section{ANTISTAPHYLOCOCCAL TREATMENT IN ATOPIC DERMATITIS PATIENTS}

Although antimicrobial treatment is not a key treatment strategy, it is implemented in the course of $\mathrm{AD}$ due to a tight correlation of $S$. aureus with exacerbation events. Moreover, the state of dysbiosis, in which lack of beneficial variability in skin microbiome during flares of the disease, is characteristic for $\mathrm{AD}$ with huge dominance of $S$. aureus, further justifies the use of antistaphylococcal approaches. Treatment of $S$. aureus colonization/infection in AD is mainly based on antibiotic therapy (topical or systemic). However, overuse of antibiotics can contribute to the development of antibiotic-resistant bacterial strains and the loss of effective antibiotic therapy (Hung et al., 2007). Sule et al. (2007) confirmed this hypothesis showing that use of topical fusidic acid by $\mathrm{AD}$ patients in the preceding 6 months contributes to the carriage of fusidic acid-resistant S. aureus strains. In Ireland, with wide use of fusidic acid for skin infections and infected $\mathrm{AD}$, resistance to this antibiotic was observed in $24 \%$ more $\mathrm{AD} S$. aureus strains than in non-atopic control (Harkins et al., 2018). The combination of the topical mupirocin ointment and topical steroids in $\mathrm{AD}$ patients revealed sound therapeutic effects manifested by the decrease in EASI and S. aureus (from $79.8 \%$ before treatment to $40.2 \%$ after treatment). In moderate and severe $\mathrm{AD}$, the combination of antibiotic and corticosteroid could be beneficial for patients at early stages of the disease. However, similar clinical effects can be obtained using topical corticosteroid alone (Gong et al., 2006).

An alternative approach in the antistaphylococcal treatment is bleach baths with sodium hypochlorite, which do not always bring the expected effect in reducing $S$. aureus colonization in infants, children and adolescents with $\mathrm{AD}$ (Hon et al., 2016; Majewski et al., 2019). The complexity of the disease results in a single treatment option being often insufficient to obtain a good.

\section{FUTURE PERSPECTIVES FOR THE ANTISTAPHYLOCOCCAL TREATMENT}

Decreased variety of commensal skin microbiota and increased S. aureus load are a key pathogenic factor in $\mathrm{AD}$ flares. Thus eradication of $S$. aureus and restoring the natural bacterial diversity in the skin is a crucial element in $\mathrm{AD}$ management, which has only recently been recognized (Hendricks et al., 2019). Topical antibiotic treatment decreases the number of $S$. aureus but clinically, not all patients benefit from such therapy. Besides spreading resistance to commonly applied antibiotics is a major concern nowadays. There can be two routes to restore the diversity of microbiome on the AD skin: (i) reintroducing natural microbial flora on the skin and/or (ii) decreasing the load of $S$. aureus. The examples of the first approach have already been proposed (Nakatsuji et al., 2017) and verified in some preliminary human trials based on the application of some representatives of coagulase-negative staphylococci (Nakatsuji et al., 2018) or yet another species, namely Roseomonas mucosa (Myles et al., 2018). The mechanism behind transplanting beneficial microorganisms directly onto the skin might be based on the production of antistaphylococcal compounds by commensal microorganisms or induction of tolerance to a pathogen. The second approach, namely decreasing the number of $S$. aureus, apart from the application of antibiotics, bleach baths or UV-based phototherapy could be obtained by the use of yet another light-based treatment, namely antimicrobial photodynamic therapy (aPDT).

The aPDT method is based on the use of a nontoxic chemical agent that is excited by visible light in the presence of oxygen. As a result of excitation reactive oxygen species (e.g., $\mathrm{O}_{2}{ }^{-}$, . $\mathrm{OH}$ and singlet oxygen $\left({ }^{1} \mathrm{O}_{2}\right)$ are produced, which damage bacterial cell wall and cellular components (DNA, proteins, lipids), finally resulting in microbial cell death (Cieplik et al., 2018). One of the main advantages of this method is the local action, with no damage to the host tissues (Wainwright et al., 2017). It was documented that aPDT degrades protein toxins by their chemical oxidation (Tubby et al., 2009). In contrast to the UV-based phototherapy, aPDT is characterized by a lack of mutagenicity (Grinholc et al., 2015). Several PS, including rose bengal and methylene blue, applied alone or in combination with antibiotics, have shown significant in vitro efficacy in eradicating $S$. aureus growing in planktonic form as well as in biofilm (Pérez-Laguna et al., 2017, 2018). Due to the severe problem with $S$. aureus colonization in $\mathrm{AD}$ patients, aPDT could be a useful tool in the antistaphylococcal treatment of chronic or/and recurrent infections (Nakonieczna et al., 2019). It is worth mentioning that the effectiveness of the aPDT method does not depend on antibiotic susceptibility patterns and resistance mechanisms.

PDT is approved in Europe for the treatment of actinic keratosis, squamous cell carcinoma in situ, and some forms of basal cell carcinoma. However, as an "off-label" treatment, PDT has also demonstrated efficacy in inflammatory and infectious dermatoses (Queirós et al., 2020). There is also one case report describing aPDI application for skin treatment in an $\mathrm{AD}$ patient. PDT using 20\% 5-aminolevulinic acid (ALA) cream was applied as a photosensitizer precursor ( $2 \mathrm{~h}$ incubation). The narrowband red light was used as a source of light $\left(630 \mathrm{~nm}, 75 \mathrm{~J} / \mathrm{cm}^{2}\right.$, $10 \mathrm{~min}$.) to treat a patient suffered from a severe lesion of $\mathrm{AD}$ located on the wrists, without signs of $S$. aureus colonization. After three sessions, one every other week, a reduction of 
the lichenification was observed, and the skin began to heal (Pozzi and Asero, 2010). More recently, daylight PDT with 5aminolevulinic acid gel (Ameluz) was used to treat chronic hand eczema, half of them for atopic dermatitis (Kremer et al., 2020). After three treatments at 2 week intervals, all the patients showed a significant clinical improvement and also in the quality of life, without significant side effects.

The results mentioned above indicated that PDT could be a promising alternative therapy for the treatment of skin inflammation as well as skin colonization in $\mathrm{AD}$ patients, where S. aureus is a predominant species.

\section{CONCLUSION}

The main question of this review was whether certain strains of $S$. aureus are more prone to colonize, infect and deteriorate atopic skin. Partially, the answer to this question is yes. MRSA is more often isolated from atopic skin than healthy. However, no specific clone can be assigned to isolates from $\mathrm{AD}$ patients, as assessed by classical genotyping methods such as PFGE or MLST. Adaptation of $S$. aureus to live on atopic skin can rather be detected at a strain-specific level and identified by the whole genome sequencing. Characterization of $S$. aureus from $\mathrm{AD}$ patients at a strain-specific level is only just beginning to be more available. The exact mechanisms responsible for the

\section{REFERENCES}

Abad, E. D., de Ferreira, D. C., Cavalcante, F. S., Saintive, S., Goudouris, E., Prado, E. A., et al. (2019). High incidence of acquiring methicillinresistant Staphylococcus aureus in Brazilian children with atopic dermatitis and associated risk factors. J. Microbiol. Immunol. Infect. 53, 724-730. doi: 10.1016/ j.jmii.2018.12.014

Akdis, C. A., Akdis, M., Bieber, T., Bindslev-Jensen, C., Boguniewicz, M., Eigenmann, P., et al. (2006). Diagnosis and treatment of atopic dermatitis in children and adults: European Academy of Allergology and Clinical Immunology/American Academy of Allergy, Asthma and Immunology/PRACTALL consensus report. Allergy Eur. J. Allergy Clin. Immunol. 118, 152-169. doi: 10.1111/j.1398-9995.2006.01153.x

Alsterholm, M., Strömbeck, L., Ljung, A., Karami, N., Widjestam, J., Gillstedt, M., et al. (2017). Variation in Staphylococcus aureus colonization in relation to disease severity in adults with atopic dermatitis during a five-month follow-up. Acta Derm. Venereol. 97, 802-807. doi: 10.2340/00015555-2667

Arikawa, J., Ishibashi, M., Kawashima, M., Takagi, Y., Ichikawa, Y., and Imokawa, G. (2002). Decreased levels of sphingosine, a natural antimicrobial agent, may be associated with vulnerability of the stratum corneum from patients with atopic dermatitis to colonization by Staphylococcus aureus. J. Invest. Dermatol. 119, 433-439. doi: 10.1046/j.1523-1747.2002.01846.x

Arkwright, P. D., Cookson, B. D., Haeney, M. R., Sanyal, D., Potter, M. R., and David, T. J. (2001). Children with atopic dermatitis who carry toxin-positive Staphylococcus aureus strains have an expansion of blood CD5B lymphocytes without an increase in disease severity. Clin. Exp. Immunol. 125, 184-189. doi: 10.1046/j.1365-2249.2001.01620.x

Aziz, F., Hisatsune, J., Yu, L., Kajimura, J., Sato'o, Y., Ono, H. K., et al. (2019). Staphylococcus aureus isolated from skin from atopic-dermatitis patients produces staphylococcal enterotoxin $\mathrm{Y}$, which predominantly induces T-Cell receptor V $\alpha$-specific expansion of $\mathrm{T}$ cells. Infect. Immun. 88:e00360-19. doi: 10.1128/IAI.00360-19

Balaban, N., and Rasooly, A. (2000). Staphylococcal enterotoxins. Int. J. Food Microbiol. 61, 1-10. interaction of $S$. aureus with the cutaneous immune system has not yet been clarified. However, the latest research results open further fields for exploration and emergence of new strategies of treatment.

\section{AUTHOR CONTRIBUTIONS}

PO performed literature search and wrote the first draft of the manuscript. YG and WB-R edited, discussed, and organized the text. JN wrote paragraphs concerning photodynamic treatment, concept of strain-specific colonization in $\mathrm{AD}$, conclusions, and edited the final version of the manuscript. All authors contributed to the article and approved the submitted version.

\section{FUNDING}

This research was supported by the National Science Centre grant No. 2017/27/BNZ7/02323 (JN).

\section{ACKNOWLEDGMENTS}

Maja Nakonieczna is acknowledged for preparation of Figure 3.

Berth-Jones, J., and Berth-Jones, J. (1996). Six area, six sign atopic dermatitis (SASSAD) severity score: a simple system for monitoring disease activity in atopic dermatitis. Br. J. Dermatol. 135(Suppl. 48), 25-30. doi: 10.1111/j.13652133.1996.tb00706.x

Blome, C., Radtke, M. A., Eissing, L., and Augustin, M. (2016). Quality of life in patients with atopic dermatitis: disease burden, measurement, and treatment benefit. Am. J. Clin. Dermatol. 17, 163-169. doi: 10.1007/s40257-015-0171-3

Bonamonte, D., Filoni, A., Vestita, M., Romita, P., Foti, C., and Angelini, G. (2019). The role of the environmental risk factors in the pathogenesis and clinical outcome of atopic dermatitis. Biomed Res. Int. 2019:2450605. doi: 10.1155/2019/ 2450605

Brazzini, B., and Pimpinelli, N. (2002). New and established topical corticosteroids in dermatology: clinical pharmacology and therapeutic use. Am. J. Clin. Dermatol. 3, 47-58. doi: 10.2165/00128071-200203010-00005

Breuer, K., HAussler, S., Kapp, A., and Werfel, T. (2002). Staphylococcus aureus: colonizing features and influence of an antibacterial treatment in adults with atopic dermatitis. Br. J. Dermatol. 147, 55-61. doi: 10.1046/j.1365-2133.2002. 04872.x

Brown, S. J., and McLean, W. H. I. (2012). One remarkable molecule: filaggrin. J. Invest. Dermatol. 132(3 Pt 2), 751-762. doi: 10.1038/jid.2011.393

Bunikowski, R., Mielke, M. E., Skarabis, H., Worm, M., Anagnostopoulos, I., Kolde, G., et al. (2000). Evidence for a disease-promoting effect of Staphylococcus aureus-derived exotoxins in atopic dermatitis. J. Allergy Clin. Immunol. 105, 814-819. doi: 10.1067/mai.2000.105528

Butaye, P., Argudín, M. A., and Smith, T. C. (2016). Livestock-associated MRSA and its current evolution. Curr. Clin. Microbiol. Rep. 3, 19-31. doi: 10.1007/ s40588-016-0031-9

Byrd, A. L., Deming, C., Cassidy, S. K. B., Harrison, O. J., Ng, W.-I., Conlan, S., et al. (2017). Staphylococcus aureus and Staphylococcus epidermidis strain diversity underlying pediatric atopic dermatitis. Sci. Transl. Med. 9:eaal4651. doi: 10.1126/scitranslmed.aal4651

Candi, E., Schmidt, R., and Melino, G. (2005). The cornified envelope: a model of cell death in the skin. Nat. Rev. Mol. Cell Biol. 6, 328-340. doi: 10.1038/nrm 1619 
Carroll, C. L., Balkrishnan, R., Feldman, S. R., Fleischer, A. B., and Manuel, J. C. (2005). The burden of atopic dermatitis: impact on the patient, family, and society. Pediatr. Dermatol. 22, 192-199. doi: 10.1111/j.1525-1470.2005.22303.x

Chan, A., and Mauro, T. (2011). Acidification in the epidermis and the role of secretory phospholipases. Dermatoendocrinology 3, 84-90. doi: 10.4161/derm. 3.2.15140

Chiesa Fuxench, Z. C., Block, J. K., Boguniewicz, M., Boyle, J., Fonacier, L., Gelfand, J. M., et al. (2019). Atopic dermatitis in America study: a cross-sectional study examining the prevalence and disease burden of atopic dermatitis in the US adult population. J. Invest. Dermatol. 139, 583-590. doi: 10.1016/j.jid.2018.08. 028

Chiu, L. S., Ho, M. S. L., Hsu, L. Y., and Tang, M. B. Y. (2009). Prevalence and molecular characteristics of Staphylococcus aureus isolates colonizing patients with atopic dermatitis and their close contacts in Singapore. Br. J. Dermatol. 160, 965-971. doi: 10.1111/j.1365-2133.2009.09038.x

Chung, H. J., Jeon, H. S., Sung, H., Kim, M. N., and Hong, S. J. (2008). Epidemiological characteristics of methicillin-resistant Staphylococcus aureus isolates from children with eczematous atopic dermatitis lesions. J. Clin. Microbiol. 46, 991-995. doi: 10.1128/JCM.00698-07

Cieplik, F., Deng, D., Crielaard, W., Buchalla, W., Hellwig, E., Al-Ahmad, A., et al. (2018). Antimicrobial photodynamic therapy-what we know and what we don't. Crit. Rev. Microbiol. 44, 571-589. doi: 10.1080/1040841X.2018.1467876

Clausen, M. L., Agner, T., Lilje, B., Edslev, S. M., Johannesen, T. B., and Andersen, P. S. (2018). Association of disease severity with skin microbiome and filaggrin gene mutations in adult atopic dermatitis. JAMA Dermatol. 154, 293-300. doi: 10.1001/jamadermatol.2017.5440

Clausen, M. L., Edslev, S. M., Andersen, P. S., Clemmensen, K., Krogfelt, K. A., and Agner, T. (2017). Staphylococcus aureus colonization in atopic eczema and its association with filaggrin gene mutations. Br. J. Dermatol. 177, 1394-1400. doi: $10.1111 /$ bjd.15470

Clausen, M. L., Edslev, S. M., Nørreslet, L. B., Sørensen, J. A., Andersen, P. S., and Agner, T. (2019). Temporal variation of Staphylococcus aureus clonal complexes in atopic dermatitis: a follow-up study. Br. J. Dermatol. 180, 181-186. doi: 10.1111/bjd.17033

Coderch, L., López, O., De La Maza, A., and Parra, J. L. (2003). Ceramides and skin function. Am. J. Clin. Dermatol. 4, 107-129. doi: 10.2165/00128071-20030402000004

Darsow, U., Lübbe, J., Taïeb, A., Seidenari, S., Wollenberg, A., Calza, A. M., et al. (2005). Position paper on diagnosis and treatment of atopic dermatitis. J. Eur. Acad. Dermatol. Venereol. 19, 286-295. doi: 10.1111/j.1468-3083.2005.01249.x

Di Nardo, A., Wertz, P., Giannetti, A., and Seidenari, S. (1998). Ceramide and cholesterol composition of the skin of patients with atopic dermatitis. Acta Derm. Venereol. 78, 27-30. doi: 10.1080/00015559850135788

Eichenfield, L. F., Call, R. S., Forsha, D. W., Fowler, J., Hebert, A. A., Spellman, M., et al. (2017). Long-term safety of crisaborole ointment $2 \%$ in children and adults with mild to moderate atopic dermatitis. J. Am. Acad. Dermatol. 77, 641.e5-649.e5. doi: 10.1016/j.jaad.2017.06.010

Faßbender, S., Opitz, F. V., Johnen, S., Förster, I., and Weighardt, H. (2017). MyD88 contributes to staphylococcal enterotoxin B-triggered atopic dermatitis-like skin inflammation in Mice. J. Invest. Dermatol. 137, 1802-1804. doi: 10.1016/ j.jid.2017.04.015

Ferreira, S., Guttman-Yassky, E., and Torres, T. (2020). Selective JAK1 inhibitors for the treatment of atopic dermatitis: focus on upadacitinib and abrocitinib. Am. J. Clin. Dermatol. 21, 783-798. doi: 10.1007/s40257-020-00548-6

Fink, P. J., Matis, L. A., McElligott, D. L., Bookman, M., and Hedrick, S. M. (1986). Correlations between T-cell specificity and the structure of the antigen receptor. Nature 321, 219-226. doi: 10.1038/321219a0

Fyhrquist, N., Muirhead, G., Prast-Nielsen, S., Jeanmougin, M., Olah, P., Skoog, T., et al. (2019). Microbe-host interplay in atopic dermatitis and psoriasis. Nat. Commun. 10:4703. doi: 10.1038/s41467-019-12253-y

Garritsen, F. M., Brouwer, M. W. D., Limpens, J., and Spuls, P. I. (2014). Photo(chemo)therapy in the management of atopic dermatitis: an updated systematic review with implications for practice and research. Br. J. Dermatol. 170, 501-513. doi: 10.1111/bjd.12645

Geoghegan, J. A., Irvine, A. D., and Foster, T. J. (2018). Staphylococcus aureus and atopic dermatitis: a complex and evolving relationship. Trends Microbiol. 26, 484-497. doi: 10.1016/j.tim.2017.11.008
Gilaberte, Y., Sanmartín, R., Aspiroz, C., Hernandez-Martin, A., Benito, D., SanzPuertolas, P., et al. (2015). Correlation between serum 25-hydroxyvitamin $\mathrm{D}$ and virulence genes of staphylococcus aureus isolates colonizing children with atopic dermatitis. Pediatr. Dermatol. 32, 506-513. doi: 10.1111/pde. 12436

Golding, G. R., Campbell, J., Spreitzer, D., and Chui, L. (2015). Pulsed-field gel electrophoresis of Staphylococcus aureus. Methods Mol. Biol. 1301, 85-93. doi: 10.1007/978-1-4939-2599-5_8

Gong, J. Q., Lin, L., Lin, T., Hao, F., Zeng, F. Q., Bi, Z. G., et al. (2006). Skin colonization by Staphylococcus aureus in patients with eczema and atopic dermatitis and relevant combined topical therapy: a double-blind multicentre randomized controlled trial. Br. J. Dermatol. 155, 680-687. doi: 10.1111/j.13652133.2006.07410.x

Grinholc, M., Rodziewicz, A., Forys, K., Rapacka-Zdonczyk, A., Kawiak, A., Domachowska, A., et al. (2015). Fine-tuning recA expression in Staphylococcus aureus for antimicrobial photoinactivation: importance of photo-induced DNA damage in the photoinactivation mechanism. Appl. Microbiol. Biotechnol. 99, 9161-9176. doi: 10.1007/s00253-015-6863-Z

Gruber, R., Elias, P. M., Crumrine, D., Lin, T.-K., Brandner, J. M., Hachem, J.-P., et al. (2011). Filaggrin genotype in ichthyosis vulgaris predicts abnormalities in epidermal structure and function. Am. J. Pathol. 178, 2252-2263. doi: 10.1016/ j.ajpath.2011.01.053

Hanifin, J. M., Cooper, K. D., Ho, V. C., Kang, S., Krafchik, B. R., Margolis, D. J., et al. (2004). Guidelines of care for atopic dermatitis. J. Am. Acad. Dermatol. 50, 391-404. doi: 10.1016/j.jaad.2003.08.003

Hanifin, J. M., and Rajka, G. (1980). Diagnostic features of atopic dermatitis. Acta Derm. Venereol. Suppl. 92, 44-47.

Hanifin, J. M., Thurston, M., Omoto, M., Cherill, R., Tofte, S. J., and Graeber, M. (2001). The eczema area and severity index (EASI): assessment of reliability in atopic dermatitis. Exp. Dermatol. 10, 11-18. doi: 10.1034/j.1600-0625.2001. 100102.x

Harkins, C. P., Pettigrew, K. A., Oravcová, K., Gardner, J., Hearn, R. M. R., Rice, D., et al. (2018). The microevolution and epidemiology of Staphylococcus aureus colonization during atopic eczema disease flare. J. Invest. Dermatol. 138, 336-343. doi: 10.1016/j.jid.2017.09.023

Harris, T. O., Grossman, D., Kappler, J. W., Marrack, P., Rich, R. R., and Betley, M. J. (1993). Lack of complete correlation between emetic and T-cellstimulatory activities of staphylococcal enterotoxins. Infect. Immun. 61, 31753183. doi: 10.1128/IAI.61.8.3175-3183.1993

Hauser, C., Wuethrich, B., Matter, L., Wilhelm, J. A., Sonnabend, W., and Schopfer, K. (1985). Staphylococcus aureus skin colonization in atopic dermatitis patients. Dermatologica 170, 35-39. doi: 10.1159/000249493

He, Y., Xie, Y., and Reed, S. (2014). Pulsed-field gel electrophoresis typing of Staphylococcus aureus isolates. Methods Mol. Biol. 1085, 103-111. doi: 10.1007/ 978-1-62703-664-1_6

Hendricks, A. J., Mills, B. W., and Shi, V. Y. (2019). Skin bacterial transplant in atopic dermatitis: knowns, unknowns and emerging trends. J. Dermatol. Sci. 95, 56-61. doi: 10.1016/j.jdermsci.2019.07.001

Holtfreter, S., Roschack, K., Eichler, P., Eske, K., Holtfreter, B., Kohler, C., et al. (2006). Staphylococcus aureus carriers neutralize superantigens by antibodies specific for their colonizing strain: a potential explanation for their improved prognosis in severe sepsis. J. Infect. Dis. 193, 1275-1278. doi: 10.1086/503048

Hon, K. L., Tsang, Y. C. K., Lee, V. W. Y., Pong, N. H., Ha, G., Lee, S. T., et al. (2016). Efficacy of sodium hypochlorite (bleach) baths to reduce Staphylococcus aureus colonization in childhood onset moderate-to-severe eczema: a randomized, placebo-controlled cross-over trial. J. Dermatolog. Treat. 27, 156-162. doi: 10. 3109/09546634.2015.1067669

Housman, T. S., Patel, M. J., Camacho, F., Feldman, S. R., Fleischer, A. B., and Balkrishnan, R. (2002). Use of the self-administered eczema area and severity index by parent caregivers: results of a validation study. Br. J. Dermatol. 147, 1192-1198. doi: 10.1046/j.1365-2133.2002.05031.x

Hung, S.-H., Lin, Y.-T., Chu, C.-Y., Lee, C.-C., Liang, T.-C., Yang, Y.-H., et al. (2007). Staphylococcus colonization in atopic dermatitis treated with fluticasone or tacrolimus with or without antibiotics. Ann. Allergy. Asthma Immunol. 98, 51-56. doi: 10.1016/S1081-1206(10)60859-9

Iwamoto, K., Moriwaki, M., Niitsu, Y., Saino, M., Takahagi, S., Hisatsune, J., et al. (2017). Staphylococcus aureus from atopic dermatitis skin alters cytokine 
production triggered by monocyte-derived Langerhans cell. J. Dermatol. Sci. 88, 271-279. doi: 10.1016/j.jdermsci.2017.08.001

Kanda, N., and Watanabe, S. (2012). Increased serum human $\beta$-defensin-2 levels in atopic dermatitis: relationship to IL-22 and oncostatin M. Immunobiology 217, 436-445. doi: 10.1016/j.imbio.2011.10.010

Kim, D.-W., Park, J.-Y., Park, K.-D., Kim, T.-H., Lee, W.-J., Lee, S.-J., et al. (2009). Are there predominant strains and toxins of Staphylococcus aureus in atopic dermatitis patients? Genotypic characterization and toxin determination of $\mathrm{S}$. aureus isolated in adolescent and adult patients with atopic dermatitis. J. Dermatol. 36, 75-81. doi: 10.1111/j.1346-8138.2009.00592.x

King, M. D., Humphrey, B. J., Wang, Y. F., Kourbatova, E. V., Ray, S. M., and Blumberg, H. M. (2006). Emergence of community-acquired methicillinresistant Staphylococcus aureus USA 300 clone as the predominant cause of skin and soft-tissue infections. Ann. Intern. Med. 144, 309-317. doi: 10.7326/00034819-144-5-200603070-00005

Kremer, N., Sherman, S., Lapidoth, M., Enk, C. D., Leshem, Y. A., Mimouni, T., et al. (2020). Self-administered daylight-activated photodynamic therapy for the treatment of hand eczema: a prospective proof-of-concept study. Dermatol. Ther. e14329. doi: 10.1111/dth.14329

Kunz, B., Oranje, A. P., Labréze, L., Stabler, J. F., Ring, J., and Taïeb, A. (1997). Clinical validation and guidelines for the scorad index: consensus report of the european task force on atopic dermatitis. Dermatology 195, 10-19. doi: $10.1159 / 000245677$

Kuo, I. H., Yoshida, T., De Benedetto, A., and Beck, L. A. (2013). The cutaneous innate immune response in patients with atopic dermatitis. J. Allergy Clin. Immunol. 131, 266-278. doi: 10.1016/j.jaci.2012.12.1563

Leung, D. Y., Harbeck, R., Bina, P., Reiser, R. F., Yang, E., Norris, D. A., et al. (1993). Presence of $\mathrm{IgE}$ antibodies to staphylococcal exotoxins on the skin of patients with atopic dermatitis. Evidence for a new group of allergens. J. Clin. Invest. 92, 1374-1380. doi: 10.1172/JCI116711

Leung, D. Y. M. (2013). New Insights into atopic dermatitis: role of skin barrier and immune dysregulation. Allergol. Int. 62, 151-161. doi: 10.2332/allergolint. 13-RAI- 0564

Leyden, J. J., and Marples, R. R. (1973). Ecologic principles and antibiotic therapy in chronic dermatoses. Arch. Dermatol. 107, 208-211. doi: 10.1001/archderm. 1973.01620170020006

Lina, G., Bohach, G. A., Nair, S. P., Hiramatsu, K., Jouvin-Marche, E., and Mariuzza, R. (2004). Standard nomenclature for the superantigens expressed by Staphylococcus. J. Infect. Dis. 189, 2334-2336. doi: 10.1086/420852

Liu, H., Archer, N. K., Dillen, C. A., Wang, Y., Ashbaugh, A. G., Ortines, R. V., et al. (2017). Staphylococcus aureus epicutaneous exposure drives skin inflammation via IL-36-Mediated T cell responses. Cell Host Microbe 22, 653.e5-666.e5. doi: 10.1016/j.chom.2017.10.006

Lo, W. T., Wang, S. R., Tseng, M. H., Huang, C. F., Chen, S. J., and Wang, C. C. (2010). Comparative molecular analysis of meticillin-resistant Staphylococcus aureus isolates from children with atopic dermatitis and healthy subjects in Taiwan. Br. J. Dermatol. 162, 1110-1116. doi: 10.1111/j.1365-2133.2010.09 679.x

Lomholt, H., Andersen, K. E., and Kilian, M. (2005). Staphylococcus aureus clonal dynamics and virulence factors in children with atopic dermatitis. J. Invest. Dermatol. 125, 977-982. doi: 10.1111/j.0022-202X.2005.23 916.x

Majewski, S., Bhattacharya, T., Asztalos, M., Bohaty, B., Durham, K. C., West, D. P., et al. (2019). Sodium hypochlorite body wash in the management of Staphylococcus aureus-colonized moderate-to-severe atopic dermatitis in infants, children, and adolescents. Pediatr. Dermatol. 36, 442-447. doi: 10.1111/ pde. 13842

Matsui, K., Nishikawa, A., Suto, H., Tsuboi, R., and Ogawa, H. (2000). Comparative study of Staphylococcus aureus isolated from lesional and non-lesional skin of atopic dermatitis patients. Microbiol. Immunol. 44, 945-947. doi: 10.1111/ j.1348-0421.2000.tb02587.x

Mempel, M., Lina, G., Hojka, M., Schnopp, C., Seidl, H.-P., Schäfer, T., et al. (2003). High prevalence of superantigens associated with the egc locus in Staphylococcus aureus isolates from patients with atopic eczema. Eur. J. Clin. Microbiol. Infect. Dis. 22, 306-309. doi: 10.1007/s10096-0030928-0

Mempel, M., Schmidt, T., Weidinger, S., Schnopp, C., Ring, J., Abeck, D., et al. (1998). Role of Staphylococcus aureus surface-associated proteins in the attachment to cultured HaCaT keratinocytes in a new adhesion assay. J. Invest. Dermatol. 111, 452-456. doi: 10.1046/j.1523-1747.1998.00293.x

Merriman, J. A., Mueller, E. A., Cahill, M. P., Beck, L. A., Paller, A. S., Hanifin, J. M., et al. (2016). Temporal and racial differences associated with atopic dermatitis Staphylococcus aureus and encoded virulence factors. mSphere 1:e00295-16. doi: 10.1128/mSphere.00295-16

Messina, J. A., Thaden, J. T., Sharma-Kuinkel, B. K., and Fowler, V. G. (2016). Impact of bacterial and human genetic variation on Staphylococcus aureus infections. PLoS Pathog. 12:e1005330. doi: 10.1371/journal.ppat.1005330

Miajlovic, H., Fallon, P. G., Irvine, A. D., and Foster, T. J. (2010). Effect of filaggrin breakdown products on growth of and protein expression by Staphylococcus aureus. J. Allergy Clin. Immunol. 126, 1184.e3-1190.e3. doi: 10.1016/j.jaci.2010. 09.015

Moriwaki, M., Iwamoto, K., Niitsu, Y., Matsushima, A., Yanase, Y., Hisatsune, J., et al. (2019). Staphylococcus aureus from atopic dermatitis skin accumulates in the lysosomes of keratinocytes with induction of IL-1 $\alpha$ secretion via TLR9. Allergy 74, 560-571. doi: 10.1111/all.13622

Murata, Y., Ogata, J., Higaki, Y., Kawashima, M., Yada, Y., Higuchi, K., et al. (1996). Abnormal expression of sphingomyelin acylase in atopic dermatitis: an etiologic factor for ceramide deficiency? J. Invest. Dermatol. 106, 1242-1249. doi: 10.1111/1523-1747.ep12348937

Myles, I. A., Earland, N. J., Anderson, E. D., Moore, I. N., Kieh, M. D., Williams, K. W., et al. (2018). First-in-human topical microbiome transplantation with Roseomonas mucosa for atopic dermatitis. JCI Insight. 3:e120608. doi: 10.1172/ jci.insight. 120608

Na, S.-Y., Roh, J.-Y., Kim, J.-M., Tamang, M. D., and Lee, J.-R. (2012). Analysis of colonization and genotyping of the exotoxins of Staphylococcus aureus in patients with atopic dermatitis. Ann. Dermatol. 24:413. doi: 10.5021/ad.2012. 24.4.413

Nada, H. A., Gomaa, N. I. M., Elakhras, A., Wasfy, R., and Baker, R. A. (2012). Skin colonization by superantigen-producing Staphylococcus aureus in Egyptian patients with atopic dermatitis and its relation to disease severity and serum interleukin-4 level. Int. J. Infect. Dis. 16, e29-e33. doi: 10.1016/j.ijid.2011.09.014

Nakagawa, S., Matsumoto, M., Katayama, Y., Oguma, R., Wakabayashi, S., Nygaard, T., et al. (2017). Staphylococcus aureus virulent PSM $\alpha$ peptides induce keratinocyte alarmin release to orchestrate IL-17-dependent skin inflammation. Cell Host Microbe 22, 667.e5-677.e5. doi: 10.1016/j.chom.2017.10.008

Nakamura, Y., Oscherwitz, J., Cease, K. B., Chan, S. M., Muñoz-Planillo, R., Hasegawa, M., et al. (2013). Staphylococcus $\delta$-toxin induces allergic skin disease by activating mast cells. Nature 503, 397-401. doi: 10.1038/nature12655

Nakatsuji, T., Chen, T. H., Narala, S., Chun, K. A., Two, A. M., Yun, T., et al. (2017). Antimicrobials from human skin commensal bacteria protect against Staphylococcus aureus and are deficient in atopic dermatitis. Sci. Transl. Med. 9:eaah4680. doi: 10.1126/scitranslmed.aah4680

Nakatsuji, T., Chen, T. H., Two, A. M., Chun, K. A., Narala, S., Geha, R. S., et al. (2016). Staphylococcus aureus exploits epidermal barrier defects in atopic dermatitis to trigger cytokine expression. J. Invest. Dermatol. 136, 2192-2200. doi: 10.1016/j.jid.2016.05.127

Nakatsuji, T., Yun, T., Butcher, A., Hayashi, A., Chun, K., Shafiq, F., et al. (2018). 426 Clinical improvement in atopic dermatitis following autologous application of microbiome therapy targeting Staphylococcus aureus. J. Invest. Dermatol. 138:S72. doi: 10.1016/j.jid.2018.03.433

Nakonieczna, J., Wozniak, A., Pieranski, M., Rapacka-Zdonczyk, A., Ogonowska, P., and Grinholc, M. (2019). Photoinactivation of ESKAPE pathogens: overview of novel therapeutic strategy. Future Med. Chem. 11, 443-461. doi: 10.4155/ fmc-2018-0329

Nienaber, J. J. C., Sharma Kuinkel, B. K., Clarke-Pearson, M., Lamlertthon, S., Park, L., Rude, T. H., et al. (2011). Methicillin-susceptible Staphylococcus aureus endocarditis isolates are associated with clonal complex 30 genotype and a distinct repertoire of enterotoxins and adhesins. J. Infect. Dis. 204, 704-713. doi: 10.1093/infdis/jir389

Niyonsaba, F., Kiatsurayanon, C., Chieosilapatham, P., and Ogawa, H. (2017). Friends or foes? Host defense (antimicrobial) peptides and proteins in human skin diseases. Exp. Dermatol. 26, 989-998. doi: 10.1111/exd.13314

Nomura, I., Tanaka, K., Tomita, H., Katsunuma, T., Ohya, Y., Ikeda, N., et al. (1999). Evaluation of the staphylococcal exotoxins and their specific IgE in childhood atopic dermatitis. J. Allergy Clin. Immunol. 104, 441-446. doi: 10. 1016/S0091-6749(99)70390-8 
Nowicki, R., Trzeciak, M., Wilkowska, A., Sokołowska-Wojdyło, M., ŁugowskaUmer, H., Barańska-Rybak, W., et al. (2015). Atopic dermatitis: current treatment guidelines. Statement of the experts of the dermatological section, polish society of allergology, and the allergology section, polish society of dermatology. Post. Dermatol. Alergol. 32, 239-249. doi: 10.5114/pdia.2015. 53319

Nutten, S. (2015). Atopic dermatitis: global epidemiology and risk factors. Ann. Nutr. Metab. 66, 8-16. doi: 10.1159/000370220

Ohnishi, Y., Okino, N., Ito, M., and Imayama, S. (1999). Ceramidase activity in bacterial skin flora as a possible cause of ceramide deficiency in atopic dermatitis. Clin. Diagn. Lab. Immunol. 6, 101-104.

Ong, P. Y., Ohtake, T., Brandt, C., Strickland, I., Boguniewicz, M., Ganz, T., et al. (2002). Endogenous antimicrobial peptides and skin infections in atopic dermatitis. N. Engl. J. Med. 347, 1151-1160. doi: 10.1056/nejmoa021481

O’Regan, G. M., and Irvine, A. D. (2008). The role of filaggrin loss-of-function mutations in atopic dermatitis. Curr. Opin. Allergy Clin. Immunol. 8, 406-410. doi: 10.1097/ACI.0b013e32830e6fb2

O’Regan, G. M., Sandilands, A., McLean, W. H. I., and Irvine, A. D. (2008). Filaggrin in atopic dermatitis. J. Allergy Clin. Immunol. 122, 689-693. doi: 10.1016/j.jaci.2008.08.002

Orfali, R. L., Yoshikawa, F. S. Y., da Oliveira, L. M. S., Pereira, N. Z., de Lima, J. F., Ramos, Y. ÁL., et al. (2019). Staphylococcal enterotoxins modulate the effector $\mathrm{CD} 4+\mathrm{T}$ cell response by reshaping the gene expression profile in adults with atopic dermatitis. Sci. Rep. 9:13082. doi: 10.1038/s41598-019-49 421-5

Ortega, E., Abriouel, H., Lucas, R., and Gálvez, A. (2010). Multiple roles of Staphylococcus aureus enterotoxins: pathogenicity, superantigenic activity, and correlation to antibiotic resistance. Toxins 2, 2117-2131. doi: 10.3390/ toxins 2082117

Park, H. Y., Kim, C. R., Huh, I. S., Jung, M. Y., Seo, E. Y., Park, J. H., et al. (2013). Staphylococcus aureus colonization in acute and chronic skin lesions of patients with atopic dermatitis. Ann. Dermatol. 25, 410-416. doi: 10.5021/ad.2013.25.4. 410

Park, J. M., Jo, J. H., Jin, H., Ko, H. C., Kim, M. B., Kim, J. M., et al. (2016). Change in antimicrobial susceptibility of skin-colonizing Staphylococcus aureus in Korean patients with atopic dermatitis during ten-year period. Ann. Dermatol. 28, 470-478. doi: 10.5021/ad.2016.28.4.470

Pascolini, C., Sinagra, J., Pecetta, S., Bordignon, V., De Santis, A., Cilli, L., et al. (2011). Molecular and immunological characterization of Staphylococcus aureus in pediatric atopic dermatitis: implications for prophylaxis and clinical management. Clin. Dev. Immunol. 2011, 1-7. doi: 10.1155/2011/718708

Patel, D., and Jahnke, M. N. (2015). Serious complications from Staphylococcal aureus in atopic dermatitis. Pediatr. Dermatol. 32, 792-796. doi: 10.1111/pde. 12665

Patel, G. K., Wyatt, H., Kubiak, E. M., Clark, S. M., and Mills, C. M. (2001). Staphylococcus aureus colonization of children with atopic eczema and their parents [2]. Acta Derm. Venereol. 81, 366-367. doi: 10.1080/ 000155501317140124

Pérez-Laguna, V., García-Luque, I., Ballesta, S., Pérez-Artiaga, L., Lampaya-Pérez, V., Samper, S., et al. (2018). Antimicrobial photodynamic activity of Rose Bengal, alone or in combination with gentamicin, against planktonic and biofilm Staphylococcus aureus. Photodiagn. Photodyn. Ther. 21, 211-216. doi: 10.1016/j.pdpdt.2017.11.012

Pérez-Laguna, V., Pérez-Artiaga, L., Lampaya-Pérez, V., García-Luque, I., Ballesta, S., Nonell, S., et al. (2017). Bactericidal effect of photodynamic therapy, alone or in combination with mupirocin or linezolid, on Staphylococcus aureus. Front. Microbiol. 8:1002. doi: 10.3389/fmicb.2017.01002

Pinchuk, I. V., Beswick, E. J., and Reyes, V. E. (2010). Staphylococcal enterotoxins. Toxins 2, 2177-2197. doi: 10.3390/toxins2082177

Pozzi, G., and Asero, R. (2010). Skin photodynamic therapy in severe localized atopic dermatitis: a case report. Br. J. Dermatol. 163, 430-431. doi: 10.1111/j. 1365-2133.2010.09823.x

Proksch, E., Brandner, J. M., and Jensen, J. M. (2008). The skin: an indispensable barrier. Exp. Dermatol. 17, 1063-1072. doi: 10.1111/j.1600-0625.2008.00786.x

Queirós, C., Garrido, P. M., Maia Silva, J., and Filipe, P. (2020). Photodynamic therapy in dermatology: beyond current indications. Dermatol. Ther. [Epub ahead of print]. doi: 10.1111/dth.13997
Rangel, S. M., and Paller, A. S. (2018). Bacterial colonization, overgrowth, and superinfection in atopic dermatitis. Clin. Dermatol. 36, 641-647. doi: 10.1016/j. clindermatol.2018.05.005

Rawlings, A. V., Scott, I. R., Harding, C. R., and Bowser, P. A. (1994). Stratum corneum moisturization at the molecular level. J. Invest. Dermatol. 124, 10991110. doi: 10.1111/1523-1747.ep12398620

Ring, J., Abeck, D., and Neuber, K. (1992). Atopic eczema: role of microorganisms on the skin surface. Allergy 47, 265-269. doi: 10.1111/j.1398-9995.1992. tb02051.x

Rodenbeck, D. L., Silverberg, J. I., and Silverberg, N. B. (2016). Phototherapy for atopic dermatitis. Clin. Dermatol. 34, 607-613. doi: 10.1016/j.clindermatol. 2016.05.011

Rojo, A., Aguinaga, A., Monecke, S., Yuste, J. R., Gastaminza, G., and España, A. (2014). Staphylococcus aureus genomic pattern and atopic dermatitis: may factors other than superantigens be involved? Eur. J. Clin. Microbiol. Infect. Dis. 33, 651-658. doi: 10.1007/s10096-013-2000-z

Roll, A., Cozzio, A., Fischer, B., and Schmid-Grendelmeier, P. (2004). Microbial colonization and atopic dermatitis. Curr. Opin. Allergy Clin. Immunol. 4, 373-378. doi: 10.1097/00130832-200410000-00008

Rustin, M. H. A. (2007). The safety of tacrolimus ointment for the treatment of atopic dermatitis: a review. Br. J. Dermatol. 157, 861-873. doi: 10.1111/j.13652133.2007.08177.x

Saravolatz, L. D., Markowitz, N., Arking, L., Pohlod, D., and Fisher, E. (1982). Methicillin-resistant Staphylococcus aureus. epidemiologic observations during a community-acquired outbreak. Ann. Intern. Med. 96, 11-16. doi: 10.7326/ 0003-4819-96-1-11

Schlievert, P. M., Case, L. C., Strandberg, K. L., Abrams, B. B., and Leung, D. Y. M. (2008). Superantigen profile of Staphylococcus aureus isolates from patients with steroid-resistant atopic dermatitis. Clin. Infect. Dis. 46, 1562-1567. doi: $10.1086 / 586746$

Schlievert, P. M., Gourronc, F. A., Leung, D. Y. M., and Klingelhutz, A. J. (2020). Human keratinocyte response to superantigens. mSphere 5:e00803-20. doi: 10. 1128/mSphere.00803-20

Schwartz, D. M., Kanno, Y., Villarino, A., Ward, M., Gadina, M., and O'Shea, J. J. (2017). JAK inhibition as a therapeutic strategy for immune and inflammatory diseases. Nat. Rev. Drug Discov. 16, 843-862. doi: 10.1038/nrd.2017.201

Silverberg, J. I. (2017). Public health burden and epidemiology of atopic dermatitis. Dermatol. Clin. 35, 283-289. doi: 10.1016/j.det.2017.02.002

Simpson, E. L., Bieber, T., Guttman-Yassky, E., Beck, L. A., Blauvelt, A., Cork, M. J., et al. (2016). Two phase 3 trials of dupilumab versus placebo in atopic dermatitis. N. Engl. J. Med. 375, 2335-2348. doi: 10.1056/nejmoa1610020

Simpson, E. L., Lacour, J. P., Spelman, L., Galimberti, R., Eichenfield, L. F., Bissonnette, R., et al. (2020a). Baricitinib in patients with moderate-to-severe atopic dermatitis and inadequate response to topical corticosteroids: results from two randomized monotherapy phase III trials. Br. J. Dermatol. 183, 242-255. doi: 10.1111/bjd.18898

Simpson, E. L., Sinclair, R., Forman, S., Wollenberg, A., Aschoff, R., Cork, M., et al. (2020b). Efficacy and safety of abrocitinib in adults and adolescents with moderate-to-severe atopic dermatitis (JADE MONO-1): a multicentre, doubleblind, randomised, placebo-controlled, phase 3 trial. Lancet 396, 255-266. doi: 10.1016/S0140-6736(20)30732-7

Soares, J., Lopes, C., Tavaria, F., Delgado, L., and Pintado, M. (2013). A diversity profile from the staphylococcal community on atopic dermatitis skin: a molecular approach. J. Appl. Microbiol. 115, 1411-1419. doi: 10.1111/jam. 12296

Spaulding, A. R., Salgado-Pabón, W., Kohler, P. L., Horswill, A. R., Leung, D. Y. M., and Schlievert, P. M. (2013). Staphylococcal and streptococcal superantigen exotoxins. Clin. Microbiol. Rev. 26, 422-447. doi: 10.1128/CMR.001 04-12

Spaulding, A. R., Satterwhite, E. A., Lin, Y. C., Chuang-Smith, O. N., Frank, K. L., Merriman, J. A., et al. (2012). Comparison of Staphylococcus aureus strains for ability to cause infective endocarditis and lethal sepsis in rabbits. Front. Cell. Infect. Microbiol. 2:18. doi: 10.3389/fcimb.2012.00018

Suh, L., Coffin, S., Leckerman, K. H., Gelfand, J. M., Honig, P. J., and Yan, A. C. (2008). Methicillin-Resistant Staphylococcus aureus colonization in children with atopic dermaitis. Pediatr. Dermatol. 25, 528-534. doi: 10.1111/j.1525-1470. 2008.00768.x 
Sule, O., Brown, N. M., Willocks, L. J., Day, J., Shankar, S., Palmer, C. R., et al. (2007). Fusidic acid-resistant Staphylococcus aureus (FRSA) carriage in patients with atopic eczema and pattern of prior topical fusidic acid use. Int. J. Antimicrob. Agents 30, 78-82. doi: 10.1016/j.ijantimicag.2007. 02.015

Syed, A. K., Reed, T. J., Clark, K. L., Boles, B. R., and Kahlenberg, J. M. (2015). Staphlyococcus aureus phenol-soluble modulins stimulate the release of proinflammatory cytokines from keratinocytes and are required for induction of skin inflammation. Infect. Immun. 83, 3428-3437. doi: 10.1128/IAI.00401-15

Taskapan, M. O., and Kumar, P. (2000). Role of staphylococcal superantigens in atopic dermatitis: from colonization to inflammation. Ann. Allergy Asthma Immunol. 84, 3-12. doi: 10.1016/S1081-1206(10)62731-7

Tomi, N. S., Kränke, B., and Aberer, E. (2005). Staphylococcal toxins in patients with psoriasis, atopic dermatitis, and erythroderma, and in healthy control subjects. J. Am. Acad. Dermatol. 53, 67-72. doi: 10.1016/j.jaad.2005.02.034

Totté, J. E. E., van der Feltz, W. T., Hennekam, M., van Belkum, A., van Zuuren, E. J., and Pasmans, S. G. M. A. (2016). Prevalence and odds of Staphylococcus aureus carriage in atopic dermatitis: a systematic review and meta-analysis. $B r$. J. Dermatol. 175, 687-695. doi: 10.1111/bjd.14566

Tubby, S., Wilson, M., and Nair, S. P. (2009). Inactivation of staphylococcal virulence factors using a light-activated antimicrobial agent. BMC Microbiol. 9:211. doi: 10.1186/1471-2180-9-211

Valour, F., Tasse, J., Trouillet-Assant, S., Rasigade, J. P., Lamy, B., Chanard, E., et al. (2014). Methicillin-susceptible Staphylococcus aureus clonal complex 398: high prevalence and geographical heterogeneity in bone and joint infection and nasal carriage. Clin. Microbiol. Infect. 20, O772-O775. doi: 10.1111/1469-0691. 12567

van Cleef, B. A. G. L., Monnet, D. L., Voss, A., Krziwanek, K., Allerberger, F., Struelens, M., et al. (2011). Livestockassociated methicillin- resistant Staphylococcus aureus in humans. Europe Emerg. Infect. Dis. 17, 502-505. doi: 10.3201/eid1703.101036

Wainwright, M., Maisch, T., Nonell, S., Plaetzer, K., Almeida, A., Tegos, G. P., et al. (2017). Photoantimicrobials-are we afraid of the light? Lancet Infect. Dis. 17, e49-e55. doi: 10.1016/S1473-3099(16)30268-7

Weidinger, S., Baurecht, H., and Schmitt, J. (2017). A 5-year randomized trial on the safety and efficacy of pimecrolimus in atopic dermatitis: a critical appraisal. Br. J. Dermatol. 177, 999-1003. doi: 10.1111/bjd.15827

Woo, T. E., and Kuzel, P. (2019). Crisaborole 2\% Ointment (Eucrisa) for atopic dermatitis. Skin Ther. Lett. 24, 4-6.
Worm, M., Simpson, E. L., Thaçi, D., Bissonnette, R., Lacour, J.-P., Beissert, S., et al. (2020). Efficacy and safety of multiple dupilumab dose regimens after initial successful treatment in patients with atopic dermatitis. JAMA Dermatol. 156:131. doi: 10.1001/jamadermatol.2019.3617

Yagi, S., Wakaki, N., Ikeda, N., Takagi, Y., Uchida, H., Kato, Y., et al. (2004). Presence of staphylococcal exfoliative toxin A in sera of patients with atopic dermatitis. Clin. Exp. Allergy 34, 984-993. doi: 10.1111/j.13652222.2004.1687.x

Yarwood, J. M., Leung, D. Y. M., and Schlievert, P. M. (2000). Evidence for the involvement of bacterial superantigens in psoriasis, atopic dermatitis, and Kawasaki syndrome. FEMS Microbiol. Lett. 192, 1-7. doi: 10.1016/S03781097(00)00400-6

Yeung, M., Balma-Mena, A., Shear, N., Simor, A., Pope, E., Walsh, S., et al. (2011). Identification of major clonal complexes and toxin producing strains among Staphylococcus aureus associated with atopic dermatitis. Microbes Infect. 13, 189-197. doi: 10.1016/j.micinf.2010.10.023

Yu, J., Luo, Y., Zhu, Z., Zhou, Y., Sun, L., Gao, J., et al. (2019). A tryptophan metabolite of the skin microbiota attenuates inflammation in patients with atopic dermatitis through the aryl hydrocarbon receptor. J. Allergy Clin. Immunol. 143, 2108.e12-2119.e12. doi: 10.1016/j.jaci.2018.11.036

Zollner, T. M., Wichelhaus, T. A., Hartung, A., Von Mallinckrodt, C., Wagner, T. O. F., Brade, V., et al. (2000). Colonization with superantigen-producing Staphylococcus aureus is associated with increased severity of atopic dermatitis. Clin. Exp. Allergy 30, 994-1000. doi: 10.1046/j.1365-2222.2000.00848.x

Zuuren, E. J., Fedorowicz, Z., and Arents, B. W. M. (2017). Emollients and moisturizers for eczema: abridged cochrane systematic review including GRADE assessments. Br. J. Dermatol. 177, 1256-1271. doi: 10.1111/bjd.15602

Conflict of Interest: The authors declare that the research was conducted in the absence of any commercial or financial relationships that could be construed as a potential conflict of interest.

Copyright (อ 2021 Ogonowska, Gilaberte, Barańska-Rybak and Nakonieczna. This is an open-access article distributed under the terms of the Creative Commons Attribution License (CC BY). The use, distribution or reproduction in other forums is permitted, provided the original author(s) and the copyright owner(s) are credited and that the original publication in this journal is cited, in accordance with accepted academic practice. No use, distribution or reproduction is permitted which does not comply with these terms. 